DIW BERLIN

Discussion

Papers

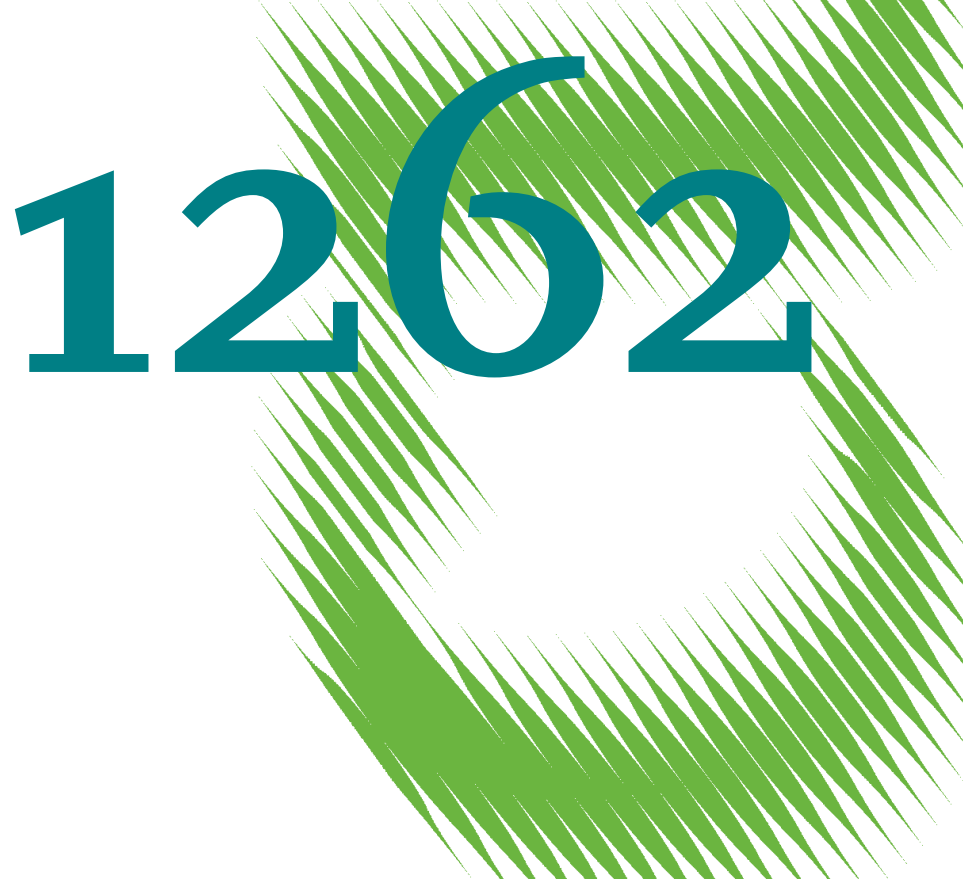

Voters Prefer More Qualified Mayors, but Does It Matter for Public Finances?

Evidence for Germany 
Opinions expressed in this paper are those of the author(s) and do not necessarily reflect views of the institute.

IMPRESSUM

(C) DIW Berlin, 2012

DIW Berlin

German Institute for Economic Research

Mohrenstr. 58

10117 Berlin

Tel. $+49(30) 89789-0$

Fax +49 (30) $89789-200$

http://www.diw.de

ISSN print edition $1433-0210$

ISSN electronic edition 1619-4535

Papers can be downloaded free of charge from the DIW Berlin website:

http://www.diw.de/discussionpapers

Discussion Papers of DIW Berlin are indexed in RePEc and SSRN:

http://ideas.repec.org/s/diw/diwwpp.html

http://www.ssrn.com/link/DIW-Berlin-German-Inst-Econ-Res.html 


\title{
Voters prefer more qualified mayors, but does it matter for public finances?
}

\section{Evidence for Germany}

\author{
Ronny Freier \\ DIW Berlin \\ Email: rfreier@diw.de \\ Sebastian Thomasius \\ Freie Universität Berlin \\ Email: sebastian.thomasius@fu-berlin.de
}

This Version: December 14, 2012

Keywords: mayoral elections; regression discontinuity design;

politician's education and experience; fiscal outcomes

JEL classification: D72; H11; H72 


\begin{abstract}
:
This paper studies the importance of politician's qualification, in terms of education and experience, for fiscal outcomes. The analysis is based on a large panel for 2,031 German municipalities for which we have collected information on municipal budgets as well as the election results and qualification levels of mayoral candidates. We principally use a Regression Discontinuity Design focusing on close elections to estimate causal effects. We find that mayors with prior experience in office indeed tend to reduce the level of local public debt, lower total municipal expenditures and decrease the local taxes. In contrast, the education level of the mayor exerts no significant effects on the overall fiscal performance of the municipality. The results are partly surprising as both education and experience are shown to matter greatly in the electoral success of mayoral candidates.
\end{abstract}

\title{
Acknowledgments:
}

We would like to thank Florian Ade, Giacomo Corneo, Peter Haan, Beate Jochimsen, Henrik Jordahl and Christian Odendahl as well as participants at Seminars at the DIW Berlin, Freie Universität Berlin, Verein für Socialpolitik in Göttingen and the Bertelsmann Foundation. Comments of colleagues at DIW Berlin, Stockholm School of Economics as well as Freie Universität Berlin are also gratefully acknowledged. Ronny Freier gratefully acknowlegdes financial support from the Fritz Thyssen foundation (Project: 10.12.2.092). We are further grateful for editorial support from Adam Lederer. The usual disclaimer applies.

\section{Mailing addresses:}

Ronny Freier: DIW Berlin, Department of Public Economics, Mohrenstr. 58, 10117 Berlin, Germany (rfreier@diw.de).

Sebastian Thomasius (corresponding author): Freie Universität Berlin, Department of Economics, Boltzmannstr. 20, 14195 Berlin, Germany (sebastian.thomasius@fu-berlin.de). 


\section{Introduction}

Politics is made by politicians and both political successes and failures are often attributed to individual political decision makers. The importance of individual politicians is also reflected in the electoral system of most modern democracies as they lead to direct elections of political leaders (e.g., mayors of municipalities in Germany, governors at the state level in the United States, or the president in France). In this setting, we would naturally presume that, first, voters take the personal characteristics of politicians into account and that, second, those attributes matter for policy outcomes once a politician gets into office. In fact, a large body of the theoretical literature in political economy takes these presumptions as the main ingredients of their models of political accountability and political agency (see Rogoff and Sibert, 1988, Besley and Case, 1995, Persson, Roland, and Tabellini, 1997).

This paper studies the empirical relevance of politicians' characteristics for electoral success and for fiscal policy outcomes in Germany. In particular, we look at direct mayoral elections in German municipalities and we evaluate the effects of a candidate's level of qualification, i.e., education and experience as indicated on the ballot sheet. In the first part of this study, the focus is on the importance of a candidate's qualification for her electoral success and whether better qualified candidates enjoy an electoral advantage. In the second part, we are then concerned with estimating the causal effect of having a competent politician in power on policy outcomes.

A number of papers in the political economy literature has confirmed that information on the ballot sheet about the specific professions of politicians indeed matter for the voter's decision. Mechtel (2011) investigates how the indicated profession of candidates for German municipal town councils affects their electoral success. He shows that candidates working in specific highly respected occupations are more likely to win elections. McDermott (2005) and Sajons (2011) highlight the informational value of statements on the ballot sheets in an experimental setting. They show that voters use the information about the candidate's professional background to update their belief about the competence or experience of the candidate and vote accordingly. $!^{1}$

Taking the impact on the electoral success as a first insight, it is an interesting empirical question whether the individual characteristics of political decision makers actually affect their political choices and policy outcomes. Besley, Montalvo, and Reynal-Querol (2011)

\footnotetext{
${ }^{1}$ Note that there is also evidence that the qualification level of politicians increases in a highly competitive political environment, which is further evidence that voters indeed put value on the qualification level of politicians (see Galasso and Nannicini, 2011, Gagliarducci and Nannicini, forthcoming; Paola and Scoppa, 2011).
} 
as well as Congleton and Zhang (2009) show that more educated political leaders can stimulate economic growth. Dreher, Lamla, Lein, and Somogyi (2009) provide evidence that the professional background of the head of government matters for the implementation of market-liberalizing reforms. Similarly, Göhlmann and Vaubel (2007) as well as Farvaque, Hammadou, and Stanek (2009, 2011) demonstrate that the educational and professional background as well as the gender of decision makers in monetary policy councils is relevant for inflation.

Other studies document similar results with respect to spending priorities and public finances. Based on data for Chinese provinces, Persson and Zhuravskaya (2011) find evidence that more public goods are provided by "inside" provincial leaders, i.e., leaders governing the province where they started and stayed during their career. On the other hand, "outside" provincial leaders, i.e., leaders originally from another province, tend to undertake more infrastructure investments. Jochimsen and Thomasius (2012) consider the role of the finance minister and show that past professional expertise gained in the financial sector makes finance ministers less likely to incur deficits.

Our analysis is based on a large panel consisting of all 2,031 municipalities in the German state of Bavaria. For these municipalities, we collected three types of data. These are, first, outcomes of mayoral elections from 1950 through 2009; second, information on the qualification level of the candidates based on the occupation indicated on the ballot sheet; and third, information on municipality budgets from 1984 through 2009. In the first part of the paper, we use a regression control framework to estimate the effect of a candidate's qualification on electoral success. We expect that voters give an electoral premium to candidates that signal higher formal qualifications on the ballot sheet. For the second part, we rely on a regression discontinuity design (RDD) methodology based on close elections in order to estimate the causal effects on fiscal outcomes. Here, we hypothesize that elected mayors with a higher level of formal qualification will work toward a lower level of debt and a higher efficiency in the provision of public goods. which will lead to lower expenditures and lower taxes.

The results of our paper are twofold. First, we indeed find a strong and significant electoral advantage for better educated candidates as well as the well-known incumbency advantage for mayors that run again for reelection. Incumbents receive a bonus of 15-18 percent in vote share or 34-41 percent increase in the probability of winning. Similarly, if the stated profession on the ballot sheet signals a university education, the candidate receives an additional 1.7-2.2 percent increase in vote share or $2.4-3.6$ percent in the probability of winning. 
Our second result is that the qualification of the mayor only has significant effects on some policy outcomes. We show that mayors who have held the mayoral position before have a tendency to reduce local public debt, lower the level of total expenditures, and decrease local taxes. While those results are only sometimes significant, they show a clear trend in the anticipated direction. When we test for the fiscal effects of education on our main outcomes, we cannot report any significant or stable effects. Overall, these results remain partly surprising and raise the question of why voters indeed seem to care about getting a highly qualified mayor into office if it does not matter much for fiscal policy.

In addition to general education and experience, we also test for the effects of having a member of a particular profession getting into the mayor's office. Here, we can run regression discontinuity designs for the following groups: (1) entrepreneurs, (2) farmers, (3) professionals from the finance sector, (4) lawyers, and (5) public employees. We find no causal effect of those groups on our main outcome variable: local public debt. For the group of farmers, however, we find that they increase all local tax rates. This is of particular interest as one of the local tax instruments is directly targeted at property in agricultural use.

Finally, the paper shows a strong and statistically significant electoral disadvantage for female politicians that goes along with an underrepresentation of women among mayors in Bavaria; however, its magnitude is unexpected. The representation of women in Bavarian mayoral elections is indeed so low that we cannot analyze potential gender effects on public finances using regression discontinuity design.

This paper proceeds as follows. Section 2 describes the institutional background of local politics in Germany and our data set. In section 3, we discuss the empirical model and the methodologies we apply. Our main results for electoral success, the effects on fiscal outcomes, and the validity of the research design are presented in section 4 . Section 5 concludes.

\section{Institutional setting and data}

\subsection{Politics and public finances at the local level in Germany}

In Germany, government activity is divided across four governmental tiers. Below the federal level, Germany is organized into 16 states, about 450 counties and approximately 12,500 municipalities. The municipal level is responsible for a number of tasks within this structure. Municipalities are directly responsible for the provision of child care, expenditures for 
culture and recreation as well as investments in local infrastructure. Moreover, they oversee local firms in the public service sector and they administrate mandated spending allocated by higher tiers. In total, German municipalities run a yearly budget of about 1,400 Euro per capita, which amounts to almost a third of all government spending..$^{2}$

Principally, municipalities receive revenues from three sources: (i) taxes and fees in their own authority; (ii) a proportion of federal taxes; and (iii) conditional transfer payments from both the state and, to some extent, the federal level. The local taxes, such as trade tax, property taxes on farmland or real estate, account for a substantial part of municipal revenues (about 20\%, see Ade and Freier 2011b). The municipalities are free to decide these tax rates themselves. A share of federal tax revenues, like income and value-added taxes, is allocated to municipalities based on fixed rules and, therefore, this source of income cannot be directly influenced by the municipalities. Conditional transfers cover specific expenditures such as infrastructure investments and administrative tasks on behalf of the federal and state level authorities.

All affairs of a municipality are part of the joint responsibility of the municipal council and the mayor. Together they are free (within limits) to decide on important infrastructure investments, actively lobby for transfers, issue public debt and/or levy local taxes. The state constitution in Bavaria grants mayors an unusually strong and independent position within local politics. The mayor is put in charge of the entire administration as well as all operative decisions. She holds active voting rights in the council and presides over all council committees. In practice, she is often the only full-time working politician and acts as the agenda setter ${ }^{3}$

The independent role of the mayor is also highlighted by the fact that the mayor is directly elected. Bavaria introduced direct mayoral elections already in 1946 shortly after World War II. 4 Generally, mayoral elections are held every six years, simultaneously with local council elections (see Ade and Freier, 2011a) $5^{5}$ The elections of local mayors follow a majoritarian electoral system with a run-off election if needed. Candidates must receive more than $50 \%$

\footnotetext{
${ }^{2}$ See Deutsche Bundesbank $(2007)$.

${ }^{3}$ Note that, under the current law, a full-time mayor is required if a municipality exceeds 10,000 inhabitants. Municipalities can have a full-time mayor if they have between 5,000 and 10,000 inhabitants. However, they may deviate and employ a part-time mayor instead. With fewer than 5,000 residents, a municipality shall have a part-time mayor but can also opt to employ a full-time mayor, see Ade and Freier (2011b).

${ }^{4}$ Other German states (except Baden-Württemberg) introduced direct elections for the mayor only after reunification, see Ade (2011).

${ }^{5}$ Note, that a municipality may deviate from the usual election dates if its mayor passed away or was removed from office.
} 
of the votes to become mayor. If no candidate wins $50 \%$ in the first ballot, a run-off election among the two leading candidates is held.

In general, one peculiarity of local elections is that political parties are less important than for elections to state or federal parliament. This is reflected in the fact that, first, candidates are often supported by several parties and, second, that both the largest group of mayoral candidates and most winning candidates are either independent or belong to a local party. In the late 1970s, several local parties merged and formed the Freie Wähler (FW) party. However, Bavaria's most important party is the politically center-right Christlich Soziale Union (CSU) 6 followed by the center-left Sozialdemokratische Partei Deuschlands (SPD). Candidates from smaller parties, such as Die Grünen (Green Party) or the liberal Freie Demokratische Partei (FDP), rarely win mayoral elections.

Given the large number of independent candidates and political parties that are only locally active, it is the individual candidate's profile and not the political party affiliation that matters. Thus, the starting point of our investigation is the information about the candidates' professional background that is provided on the ballot sheet next to the names and the supporting party or parties of each candidate.

\subsection{Data}

In the remainder of this article, we investigate two different aspects of mayoral elections. First, we focus solely on the election outcomes and the influence of the candidates' characteristics on their vote share and their probability of winning. Then, we look at the effect of the characteristics of the elected mayor on fiscal outcomes using a regression discontinuity design in which we rely on close elections. While the empirical methodology is discussed in detail later on, we introduce our unique data set in the following paragraphs.

Our data comprises both the information from the ballot sheet and the results of mayoral elections in all 2,031 municipalities in Germany's federal state of Bavaria from 1950 through 2009: 7 Figure 1 in the appendix depicts a sample ballot sheet from one mayoral election in our data set. In total, we observe the results of 25,051 elections ${ }^{8}$ with 43,371 candidates

\footnotetext{
${ }^{6}$ The CSU exists only in the federal state of Bavaria. At the federal level, the party is closely connected with the Christlich Demokratische Union (CDU) and forms one group within the federal parliament.

${ }^{7}$ Together with 25 independent cities, there are a total of 2,056 authorities at the lowest tier in Bavaria. Out of the 12.5 million inhabitants in Bavaria in 2007, roughly 9 million live in those 2,031 municipalities and the remaining 3.5 million in the independent cities.

${ }^{8}$ Initially, our data set included 25,085 elections since 1950 . However, we excluded 34 elections due to missing information about the total number of voters or incomplete election results. Among them are 22 elections with only one candidate.
} 
(see table 1); thereof 2,473 are close elections with a margin of victory of no more than $10 \%$ for the winner and out of those 1,254 with no more than 5\%. In 21,233 elections, one candidate received a clear majority of votes, while a run-off election was needed after 1,901 elections. In 1,892 cases, a mayor was elected in a run-off election..$^{9}$ Further descriptive statistics on the election data are presented in table 9 in the appendix.

Table 1: Number of elections and candidates by election outcome

\begin{tabular}{|c|c|c|c|c|c|c|}
\hline & \multicolumn{3}{|c|}{ Elections } & \multicolumn{3}{|c|}{ Candidates } \\
\hline & All & $10 \%$ window & $5 \%$ window & All & $10 \%$ window & $5 \%$ window \\
\hline \multicolumn{7}{|l|}{ Successful elections } \\
\hline Clear election result & 21,233 & 1,595 & 796 & 33,623 & 3,221 & 1,594 \\
\hline Run-off election & 1,892 & 874 & 454 & 3,783 & 1,748 & 908 \\
\hline Coin toss (same votes) & 4 & 4 & 4 & 8 & 8 & 8 \\
\hline Total & 23,129 & 2,473 & 1,254 & 37,414 & 4,977 & 2,510 \\
\hline \multicolumn{7}{|l|}{ No mayor elected } \\
\hline Run-off election needed & 1,901 & - & - & 5,916 & - & - \\
\hline Invalid election & 21 & - & - & 41 & - & - \\
\hline Total & 1,922 & - & - & 5,957 & - & - \\
\hline Total & 25,051 & 2,473 & 1,254 & 43,371 & 4,977 & 2,510 \\
\hline
\end{tabular}

Party cooperation and joint nominations are common for mayoral elections in Bavaria; we observe 8,745 candidates nominated by at least two parties. However, the CSU clearly dominates the political arena in Bavaria and is the party with the largest number of candidates, some 9,483. The SPD follows with 6,173 candidates. The minor parties and independent election groups had a total of 16,948 candidates, while 2,022 candidates indicated no party affiliation at all.

There are 3,997 different professions indicated on the ballot sheet for all candidates running for the mayor's office between 1950 and 2009. Based on this information, we assess the education level of each candidate and generate the variable university representing the probability that a candidate is a university graduate (including both universities and universities of applied sciences). The first step in our assessment is to classify all those candidates as university graduates who either explicitly indicate that they hold a university degree or work in a profession legally requiring a university degree in Germany (e.g., teachers, physician or lawyers). Consequently, the variable university takes the value of one

\footnotetext{
${ }^{9}$ The difference between 1,901 elections without a result and causing a run-off election and only 1,892 run-off elections held in our sample is largely due to the elections that were excluded due to incomplete data. Recall, there was only one candidate for the majority of excluded elections, see footnote 8 .
} 
for those candidates. Then, we draw on the average share of university graduates within a specific occupation category for the remaining candidates as a second step. For that purpose, we group all candidates into 105 specific professional clusters matching Germany's official job-classification system and use the average share of university graduates within the respective professional group. 10 Table 10 in the appendix illustrates the wide range of qualification levels along different industry clusters.

More than 16,000 candidates indicate the occupation 'mayor' on the ballot sheet. In these cases we use the occupation that was indicated in the election when the candidate was elected into the mayor's office for the first time in order to obtain the probability that the candidate holds a university degree. Furthermore, we use this information to identify more experienced candidates that have already served as a mayor and gained on-the-job experience.

It is striking how underrepresented women are among local politicians in Bavaria. Between 1950 and 2009, there were only 1,442 female candidates, representing $3.3 \%$ of all candidates in our full sample of 43,371 candidates. Female candidates were elected mayor in only 314 out of 23,129 elections; with 41 close elections where the margin of victory did not exceed $5 \% 11$ Given these low numbers, we are not able to draw upon any statistical interference using the regression discontinuity design and, therefore, we cannot investigate whether female mayors act differently and realize different fiscal outcomes. Nevertheless, we can analyze how the gender of candidates affects their vote share and the likelihood to win an election.

After the analysis of the effect of the candidates' education and profession on their electoral success, we investigate their impact on the fiscal outcomes of the municipality. Our analysis is based on a unique data set comprising fiscal information of the 2,031 municipalities in Bavaria between 1984 and 2009. The data includes the municipal debt level, total expenditures as well as three local tax rates (trade tax, property taxes A on land, and

${ }^{10}$ We rely on the national, so-called 'Classification System of Occupations 1988' (Klassifikation der Berufe or KldB 1988) used by Germany's Federal Employment Agency (BA), who provided us with the data. The data covers all employees subject to social insurance contributions in Bavaria. Due to limited data availability, we assigned the share of university graduates in 1999 to all candidates running for election before December 31, 2000, and the share of graduates in 2009 to all candidates running for election thereafter. In both cases we assign the gender-specific shares of graduates, i.e., a female candidate working as a farmer is assigned the average share of university graduates among women working in agriculture and a male candidate, respectively, the share of graduates among men.

${ }^{11}$ At the federal and state level, female representation is much higher, with more than $30 \%$ female members of parliament (Bundestag) and about $30 \%$ female members of state parliaments. Given that approximately $50 \%$ of the population is female, these shares are still well below the population mean (McKay, 2004). 
property tax B on real estate). Descriptive statistics for those fiscal outcome variables are contained in table 2 ,

Table 2: Descriptive statistics of fiscal data (1984-2009)

\begin{tabular}{lccccc}
\hline \hline \multicolumn{1}{c}{ Variable } & Observations & Mean & Std. dev & Min & Max \\
\hline Debt per capita & 7,984 & 55.968 & 361.587 & $-4,031$ & 4,144 \\
Expenditures per capita & 8,333 & 183.976 & 695.662 & $-6,435$ & 21,741 \\
& & & & & \\
& 8,333 & 6.111 & 22.247 & -220 & 500 \\
Property tax A (multiplier) & 8,333 & 7.321 & 21.982 & -170 & 500 \\
Property tax B (multiplier) & 8,333 & 2.771 & 12.234 & -150 & 140 \\
Trade tax (multiplier) & \multirow{2}{*}{$\begin{array}{l}\text { Notes: The table shows the descriptive statistics for the fiscal data used in the analysis, i.e., the change } \\
\text { None }\end{array}$} \\
over five years following a mayoral election in the respective variable. Data on debt, expenditures are \\
per capita in Euro and tax rate multipliers for the tax rates. Source: Own calculations, based on the \\
data provided by the state statistical office of Bavaria.
\end{tabular}

We assess the impact on public finances from three different angles. First, we investigate the effect of on-the-job experience when an incumbent runs for reelection. Second, we look at the effect of the mayor's education level. Table 3 summarizes the two different samples used here. A third angle focuses on specific professions of the mayor. This analysis considers the following five professions: entrepreneurs, farmers, professionals with financial expertise, lawyers and public employees.

Table 3: Samples used in the regression discontinuity analyses

\begin{tabular}{lccccc}
\hline \hline & \multicolumn{2}{c}{ Experience } & & \multicolumn{2}{c}{ Education } \\
\cline { 2 - 3 } \cline { 5 - 6 } \cline { 5 - 6 } & Elections & Municipalities & & Elections & Municipalities \\
\hline Full sample & 3.093 & 1.529 & & 3.544 & 1.673 \\
$10 \%$ window & 487 & 416 & & 615 & 527 \\
$5 \%$ window & 264 & 241 & & 291 & 271 \\
\hline
\end{tabular}

Notes: The table shows the samples (1984-2009) used in the regression discontinuity design (RDD). The sample sizes differ because only those elections in which the winning mayor and the best opponent differ in terms of education and previous experience as a mayor are included. Source: Own calculations, based on the data provided by the state statistical office of Bavaria. 


\section{Empirical model and methodology}

In this section, we will introduce the main methodological tool, regression discontinuity design (henceforth RDD). This empirical strategy was first developed by Thistlethwaite and Campbell (1960) in educational science and has since been frequently used in economics and especially political economic research (see Lee, 2008, Pettersson-Lidbom, 2008, Ade and Freier, 2011a). For the exposition here, we closely follow Freier (2011).

We will first lay out the implementation of a fuzzy RDD that will be used in the analysis of the effect of mayor education on fiscal outcome variables. Thereafter, we will introduce the sharp RDD that we apply to identify the effects of experience and when we look at specific professional groups.

\subsection{Fuzzy regression discontinuity design}

Denote the education level of the winner of an election with $e d u_{w}$ and for the best opponent with $e d u_{o}$. These variables can take the value 0 (no university degree), 1 (sure university degree), or a value inbetween that reflects the average university graduates for the indicated occupation category of the candidate. Define treatment $d_{i}$ where the $i$ refers to the unit of observation (we omit a time index $t$ ) where $d_{i}=e d u_{w}$, which represents the true education level of the newly elected mayor.

Now, consider only observations in which the winner and the best opponent have different levels of education $e d u_{w} \neq e d u_{o}$. Define the vote share of the more highly educated candidate with $v_{h}$ and for the lower educated candidate with $v_{l}$. The margin of victory, $m$ with $m=v_{h}-v_{l}$, then, determines whether the higher educated candidate gets into office (with the cutoff at $\mathrm{m}=0)$. At $\mathrm{m}=0$, we will thus have a discontinuity in the treatment variable $d_{i}$. As this discontinuity is not sharp (the change is not neccessarily from 0 to 1 ), the design is only fuzzy. We implement the fuzzy RDD as an instrumental variable (IV) estimator.

We are interested in evaluate the effect of treatment $d_{i}$ on an fiscal outcome $y_{i}$. The second stage of the IV estimator is as follows:

$$
y_{i}=\beta_{0}+\beta_{1} d_{i}+X \gamma+f(m)+\epsilon_{i}
$$

where the set of control variables $X$ includes linear and squared terms of the local population number as well as year fixed effects. The function $f(m)$ is a polynomial in the margin of victory that captures the impact of the vote margin on the fiscal outcome.

To focus on exogenous variation in $d_{i}$, we use a first stage in the IV as follows: 


$$
d_{i}=\delta_{0}+\delta_{1} z_{i}+X \gamma+f(m)+\epsilon_{i}
$$

where $z_{i}$ is an indicator variable that takes the value one if the margin of victory $\mathrm{m}$ is larger than 0 .

The intuition of the RDD is to focus on the observations just around the threshold. Assuming that the margin of victory $m_{i}$ cannot be precisely manipulated by the candidates, observations just right and left of the decisive threshold $(m=0)$ should have the same characteristics both observable and unobservable. Treatment (the level of education of the mayor), however, will be different just right and just left, which allows for causal inference. The formal argument for the validity of this approach is the continuity assumption as pointed out by Hahn, Todd, and Klaauw (2001) as well as Lee and Lemieux (2010). Around the threshold, all characteristics, except treatment must be distributed continuously.

In practice that means that two conditions must be met. First, the score variable (here margin of victory) has to include some random element. We must have that the score variable was really close to the threshold. Whether it then ended up just left or just right to the threshold must be the result of a random event. Secondly, the treatment at this threshold must be unique, meaning that no other influences change at the same threshold.

For our application this implies that an election between a highly educated candidate against a not as well educated opponent must have been decided by random chance if the election was a very close race. Then, the vote margin between the two candidates effectively determined treatment (the education level of the mayor) randomly. If the highly qualified candidate received more votes than the opponent, the municipality will have a qualified mayor. If she just lost, the mayor will not have as high educational attainment.

We should point out the local nature of the estimate. The LATE (local average treatment effect) that we estimate will draw inference only from observations for which two candidates with different levels of education saw one candidate just winning the election. Our results will be internally valid, because observation just right and just left to the threshold have similar characteristics. But what can we say about external validity? Observations in which a highly qualified candidate won which a big vote margin might be very different from the observations that we consider, so the results should only be generalized with care.

\subsection{Sharp regression discontinuity design}

For the analysis of experience of the mayor on fiscal outcome, we will use a sharp RDD

that relies on a similar idea as developed above. Assume that an incumbent mayor runs 
against a newcomer. Again, if the election between those two candidates was sufficiently close, whether the town gets an experienced mayor or not is subject to the outcome of a random event.

For this analysis, consider the following (alternative) margin of victory, $m$ :

$$
m=v_{i}-v_{n}
$$

where $v_{i}$ is the vote share of the incumbent and $v_{n}$ is the share of votes for the newcomer. At $m=0$, it is determined whether the incumbent will serve an additional term.

Now, define the new treatment, $d_{i}$ as an indicator variable of whether the new mayor has experience (was incumbent before) or not. We see that $m$ uniquely determines $d$ :

$$
d=1[m>0]
$$

Given that the relationship is deterministic (thus the name sharp RDD), we do not have to go via an instrumental variable estimation to make use of this discontinuity. We can implement the following specification:

$$
y^{i}=\beta_{0}+\beta_{1} d_{i}+X \gamma+f(m)+\epsilon_{i, t}
$$

where the variables are defined as above and the flexible function $f(\cdot)$ then represents the influence of the margin of victory on the fiscal outcome.

The identifying assumption is that by introducing the flexible functional form $f(m)$ of the margin of victory in the full sample regression, any correlation of treatment with omitted variables in the error term can be controlled for. Note that, this control function needs to be correctly specified for the assumption to hold. In practice, we apply a number of different parametric polynomial specifications with varying degrees in the polynomial to show that the effects are not sensitive to the precise choice of functional form. Also, we will present nonparametric estimates of the above specification based on the optimal bandwidth estimator developed by Imbens and Kalyanaraman (2012).

Again, we want to draw the attention to the local characteristics of our estimator. Inference is drawn from observation in which an incumbent mayor just won or lost against a newcomer. External validity, however, is harder to argue. Indeed, one may ask if an incumbent that just won or lost is of the same characteristics as just any incumbent. We emphasize that this is only a constraint to external validity while internal validity is given if election outcomes at the margin are subject to some randomness. 
The idea of the sharp RDD will be used also when we evaluate the effect of having a mayor with a specific former occupation who gets into office. The methodology of identification is just as described above. The only difference is that we structure the data such that we can see whether a candidate with a specific occupation just won or lost against an opponent. The data allow us to implement such analyses for entrepreneurs, farmers, professionals with financial expertise, lawyers and public employees.

\section{Results}

The discussion of our results consists of four parts. The first part presents our findings regarding the effects of a candidate's education and experience on her electoral success (section 4.1). Then we discuss the causal effects on the fiscal outcomes of the major's experience in office and his education $(4.2)$ and mayors with specific professions and characteristics (4.3). Finally, we provide a battery of tests showing the validity of our RDD approach (4.4).

\subsection{Effects of education and experience on electoral success}

The first part of our analysis focuses on the effect of individual characteristics of mayoral candidates on their electoral success. We present evidence from a simple regression control framework in which we relate the vote share of a candidate to the observable characteristics (incumbent mayor, university graduate, gender, occupation). ${ }^{12}$ Table 4 holds the results for this analysis. The estimates clearly indicate that individual characteristics of candidates in Bavarian mayoral elections matter for the electoral outcomes.

First, we can document the well-known legislator incumbency advantage effect (in row 1). Incumbent candidates enjoy a highly significant electoral advantage of about 15-18 percentage points in vote share compared to other candidates. Notably, the results are well in line with the evidence presented by Freier (2011). Freier applies a causal inference approach and shows a party incumbency effect of about 14-16 percentage points in the vote share 13

\footnotetext{
${ }^{12}$ The results are based on OLS regression using data for all elections between 1950 and 2009 in 2,031 German municipalities from Bavaria. Using a restricted sample with elections between 1984 and 2009 only (as for the analysis on fiscal outcomes), we obtain almost exactly similar results. Results are not shown here, but are available upon request.

${ }^{13}$ Note, that the estimate in our paper refers to the individual legislator incumbency advantage instead of the party incumbency advantage. The difference is that here we consider the advantage for the single candidate and not for her party. While we can only use a simple regression control framework in our setting, Freier (2011) can rely on a RDD approach to have exogenous variation in the party identity of the previous mayor and estimates the advantage to any candidate of that party in the next election.
} 
Table 4: Electoral success and characteristics of mayoral candidates: Vote share

\begin{tabular}{|c|c|c|c|c|c|}
\hline & \multicolumn{5}{|c|}{ OLS } \\
\hline & (1) & $(2)$ & $(3)$ & $(4)$ & $(5)$ \\
\hline Incumbent & $\begin{array}{c}0.176^{* * *} \\
(0.002)\end{array}$ & $\begin{array}{c}0.181^{* * *} \\
(0.002)\end{array}$ & $\begin{array}{c}0.158^{* * *} \\
(0.003)\end{array}$ & $\begin{array}{c}0.158^{* * *} \\
(0.003)\end{array}$ & $\begin{array}{c}0.151^{* * *} \\
(0.003)\end{array}$ \\
\hline $\begin{array}{l}\text { Interaction } \\
\text { (\# of voters } * \text { incumbent })\end{array}$ & & & $\begin{array}{c}0.090^{* * *} \\
(0.006)\end{array}$ & $\begin{array}{c}0.087^{* * *} \\
(0.006)\end{array}$ & $\begin{array}{c}0.085^{* * *} \\
(0.006)\end{array}$ \\
\hline Dummy university & & $\begin{array}{c}0.022^{* * *} \\
(0.002)\end{array}$ & & & \\
\hline University & & & $\begin{array}{c}0.017^{* * *} \\
(0.003)\end{array}$ & $\begin{array}{c}0.017^{* * *} \\
(0.003)\end{array}$ & $\begin{array}{c}0.018^{* * *} \\
(0.004)\end{array}$ \\
\hline $\begin{array}{l}\text { Interaction } \\
\text { (\# of voters } * \text { university) }\end{array}$ & & & $\begin{array}{c}0.029^{* * *} \\
(0.006)\end{array}$ & $\begin{array}{c}0.028^{* * *} \\
(0.006)\end{array}$ & $\begin{array}{c}0.027^{* * *} \\
(0.006)\end{array}$ \\
\hline Female candidate & & & & $\begin{array}{c}-0.051^{* * *} \\
(0.004)\end{array}$ & $\begin{array}{c}-0.050 * * * \\
(0.004)\end{array}$ \\
\hline $\begin{array}{l}\text { Set of Dummies for Jobs (F-Stat) } \\
\text { (p-value in parentheses) }\end{array}$ & & & & & $\begin{array}{l}21.91 \\
(0.00)\end{array}$ \\
\hline Observations & 43,371 & 43,128 & 42,349 & 42,349 & 42,349 \\
\hline $\mathrm{R} 2$ & 0.74 & 0.74 & 0.74 & 0.74 & 0.74 \\
\hline
\end{tabular}

Notes: Significance levels: ${ }^{*} p<0.10,{ }^{* *} p<0.05,{ }^{* * *} p<0.01$. Standard errors in parentheses are robust and clustered on the level of each individual municipality election. All results presented are derived from OLS regressions and always include year and county fixed effects that are not shown here. Furthermore, the regressions include a set of dummy variables for the party of the candidate and for the respective total number of candidates in elections with more than one candidate, which are also not presented. The dependent variable is the vote share of the individual candidate. The regression in column 1 highlights the effect of a candidate being the incumbent in an election. In columns 2 and 3, we add variables on the education level of the candidate. First, we add a dummy indicating whether a candidate holds a university degree with certainty (university and university of applied sciences). Second, we include our constructed measure of the expected education level as well as its interaction with the number of voters (in 10 tsd). In column 4 we include dummy variables for whether the candidate is female. Finally, in column 5 we add a set of dummies for the 14 job categories described in table 10 in the appendix (the table here highlights the F-test statistic for joined significance and the p-value of that test statistic is given in parentheses). Source: Own calculations.

In column 2, we add a dummy variable indicating whether a candidate signals a university degree on the ballot sheet (including graduates from universities of applied science) or those candidates working in any occupation requiring a university degree. At this stage, we only code this dummy to be one if the information on the ballot leaves no doubt about the true education status of the candidate. We find that candidates with a university degree receive a vote share that is a significant 2.2 percentage points higher than other candidates.

In models 3 to 5 we instead include a different variable university. Here, we use the share of university graduates in the candidate's occupation group. This variables is continuous and takes values between 0 and 1 . Similar to before, our estimates for this characteristic 
in columns $3-5$ show that candidates with a university degree enjoy as significant electoral advantage of $1.7-1.8$ percentage points in vote share.

Furthermore, we include two interaction terms that test for the heterogeneity in the qualification effects with regard to the size of the constituency. We interact both the experience on the job (incumbency status) as well as our measure for education (university) with the number of voters. Both interaction terms (in columns 3-5) have positive signs and are statistically significant. An incumbent in an election with an additional 10,000 voters enjoys an extra advantage of 9 percentage points in vote share. Similarly, a candidate with an occupation requiring a university degree will receive an additional vote share of 2.9 percentage points with every 10,000 additional voters. ${ }^{14}$

In column 4, we further include the gender of the candidate, which does not change our previous findings. However, we show that female candidates suffer from an electoral disadvantage and receive 5.4 percentage points fewer votes than male candidates. This effect is statistically significant at the $1 \%$ level.

Finally, in model 5, we also include dummies for specific occupational groups and find strong support for our hypothesis that the information on the ballot sheet affects the electoral success of candidates. While these specific dummy variables are jointly statistically significant, the coefficients of the other variables do not really change. Here, our result confirms the evidence by Mechtel (2011) who argues for the importance of occupation information in local council elections.

We repeat the analysis using the probability of winning as outcome variable and confirm that the above effects are also of equal importance for the actual chance to win an election (see table 11 in the appendix). As expected, all coefficients show similar sign and significance and are larger in value than for the vote share.

Our results show that the candidate's experience and her implied education significantly affect her electoral success both in vote shares and in the probability of winning. The effects are reinforced as the population of a municipality becomes larger. Specific job groups also positively affect the electoral success. Female candidates, however, suffer from

\footnotetext{
${ }^{14}$ There are two arguments that may explain the positive results on the two interaction terms. Firstly, the electoral premium for qualification increases in towns with larger populations as the mayoral position requires a larger skill set. Voters may put more focus on the ballot sheet information about the qualification of the candidate when it matters more. Secondly, we may also assume that the informational value of the ballot sheet is greater in big towns than in smaller villages. Voters in small municipalities may personally know the candidates and rely less on ballot sheet information, while the electorate in larger cities receives a more informative signal from the ballot.
} 
an electoral disadvantage of more than $5 \%$ in vote share and $10 \%$ in probability of winning. This electoral disadvantage might explain the surprisingly low overall number of female candidates as well and is well in line with the finding of McKay (2004) that women are significantly underrepresented in top-level positions at the state and federal level in German politics.

\subsection{Education and incumbency experience on fiscal outcomes}

In this subsection, we highlight the results for the causal effect of mayor qualification, i.e., education and experience, on fiscal outcomes of the municipalities. We will mainly show two sets of results: (1) for the most aggregate fiscal outcomes debt and expenditures and (2) for local taxes as the main revenue sources under the discretion of the municipality.

Table 5 shows the results for our main outcome variables, debt and expenditures. We look at changes in debt and expenditures from just prior to the start to the very end of the election period. Panel 1 indicates the results for our measure of experience (incumbency status), while panel 2 holds the findings for the education variable. Columns 1 and 2 present estimates of simple OLS and Fixed Effects (FE) models respectively. In columns 3 to 7 , we show the results of different RDD specifications. Here, columns 3 and 4 use a global parametric estimation procedure in which we use the entire sample and specify a linear or fourth order control function. Columns 5-7 use specifications in which we limit the sample around the threshold. The bandwidth is $10 \%$ in the margin of victory in column $5,5 \%$ in column 6 and an optimal bandwidth (based on the algorithm proposed by Imbens and Kalyanaraman, 2012) in column 7.

For the analysis of the effect of experience (panel 1), we find a tendency for more experienced mayors, i.e., mayors that have been in office before, to lower the local public debt and decrease total expenditures. The sign of the effect thus goes in the expected direction. For the five-year change in public debt, we find that the estimates in all RDD specifications are negative and in two cases also marginally significant. For the outcome of total municipal expenditures all estimates (also in the OLS and FE specifications) show a negative sign. Overall, we must note that despite the clear negative trend and the substantial economic size of the effect the estimates are imprecisely estimated and remain mostly insignificant. Given this lack of significance, we may not put too much weight on those results.

The results of the effect of education show high sensitivity both in sign and size. For local public debt, we see no clear pattern in direction and estimates are far from significant. For the outcome variable of total expenditures, estimates are positive throughout, however, 
Table 5: Qualification and key public finance indicators

\begin{tabular}{|c|c|c|c|c|c|c|c|}
\hline & \multirow{2}{*}{$\frac{\mathrm{OLS}}{(1)}$} & \multirow{2}{*}{$\frac{\mathrm{FE}}{(2)}$} & \multicolumn{2}{|c|}{ Global parametric RDD } & \multicolumn{3}{|c|}{ Discontinuity-sample RDD } \\
\hline & & & $(3)$ & $(4)$ & $(5)$ & (6) & (7) \\
\hline & \multicolumn{7}{|c|}{ Panel 1: Experience } \\
\hline Debt & $\begin{array}{c}7.51 \\
(21.81) \\
{[2.928]}\end{array}$ & $\begin{array}{c}10.62 \\
(26.05) \\
{[2.928]}\end{array}$ & $\begin{array}{l}-22.59 \\
(36.70) \\
{[2.928]}\end{array}$ & $\begin{array}{l}-65.42 \\
(68.16) \\
{[2.928]}\end{array}$ & $\begin{array}{c}-134.15^{*} \\
(75.55) \\
{[457]}\end{array}$ & $\begin{array}{c}-165.74^{*} \\
(95.69) \\
{[248]}\end{array}$ & $\begin{array}{c}-28.58 \\
(43.06) \\
-\end{array}$ \\
\hline \multirow[t]{2}{*}{ Expenditures } & $\begin{array}{l}-41.98 \\
(34.17) \\
{[3.019]}\end{array}$ & $\begin{array}{l}-28.39 \\
(43.15) \\
{[3.019]}\end{array}$ & $\begin{array}{l}-51.29 \\
(65.69) \\
{[3.019]}\end{array}$ & $\begin{array}{c}-136.05 \\
(145.02) \\
{[3.019]}\end{array}$ & $\begin{array}{c}-81.49 \\
(133.10) \\
{[471]}\end{array}$ & $\begin{array}{c}-245.69 \\
(219.27) \\
{[258]}\end{array}$ & $\begin{array}{c}-127.69 \\
(94.54) \\
-\end{array}$ \\
\hline & \multicolumn{7}{|c|}{ Panel 2: Education } \\
\hline Debt & $\begin{array}{c}23.80 \\
(15.47) \\
{[3.312]}\end{array}$ & $\begin{array}{l}52.23^{*} \\
(27.52) \\
{[3.312]}\end{array}$ & $\begin{array}{c}5.99 \\
(49.04) \\
{[3.312]}\end{array}$ & $\begin{array}{c}-17.06 \\
(119.64) \\
{[3.312]}\end{array}$ & $\begin{array}{c}88.18 \\
(145.44) \\
{[570]}\end{array}$ & $\begin{array}{c}-151.73 \\
(220.46) \\
{[274]}\end{array}$ & $\begin{array}{c}61.68 \\
(94.34) \\
-\end{array}$ \\
\hline Expenditures & $\begin{array}{c}0.23 \\
(27.41) \\
{[3.440]}\end{array}$ & $\begin{array}{c}43.86 \\
(56.25) \\
{[3.440]}\end{array}$ & $\begin{array}{c}162.95 \\
(104.68) \\
{[3.440]}\end{array}$ & $\begin{array}{c}169.81 \\
(191.36) \\
{[3.440]}\end{array}$ & $\begin{array}{c}144.01 \\
(217.00) \\
{[587]}\end{array}$ & $\begin{array}{c}19.63 \\
(324.24) \\
{[282]}\end{array}$ & $\begin{array}{c}123.32 \\
(120.47) \\
-\end{array}$ \\
\hline $\begin{array}{l}\text { Control function } \\
\text { Sample size }\end{array}$ & $\begin{array}{l}\text { none } \\
\text { full }\end{array}$ & $\begin{array}{l}\text { none } \\
\text { full }\end{array}$ & $\begin{array}{l}\text { linear } \\
\text { full }\end{array}$ & $\begin{array}{l}\text { 4th order } \\
\text { full }\end{array}$ & $\begin{array}{l}\text { linear } \\
+/-10 \%\end{array}$ & $\begin{array}{l}\text { linear } \\
+/-5 \%\end{array}$ & $\begin{array}{l}\text { linear } \\
\text { optimal }\end{array}$ \\
\hline
\end{tabular}

Notes: Significance levels: $* p<0.10, * * p<0.05, * * * p<0.01$. Standard errors in parentheses are robust. The number of observations for each regression is stated in square brackets. Dependent variables are indicated in the left column. They refer to changes in yearly per capita data (the change over five years from the election year to the year before the next election). Results are reported for different estimations for education (fuzzy RDD) and on-the-job experience as a mayor ("sharp" RDD). Note, that results for education in the fuzzy RDD refer to the second-stage IV regression and each coefficient is the estimate on the variable of whether the mayor is highly educated instrumented from a separate first-stage regression. All regressions include linear and squared controls for the number of inhabitants in the municipalities as well as year fixed effects. Column 1 shows the OLS results, column 2 the results for a simple fixed effects estimation (with municipality fixed effects). In columns 3 and 4 we present results of the parametric implementation (global polynomial) with control functions of the first and fourth order. Results from different non-parametric implementations are reported in columns 5 to 7 . In the last column, we implemented the optimal bandwidth estimator by Imbens and Kalyanaraman (2012). The optimal bandwidth for experience ranges from $+/-25.2 \%$ for total expenditures and $+/-30.2 \%$ for public debt, for education it ranges from $+/-21.6 \%$ for public debt and $+/-45.2 \%$ for expenditures. All control functions are specified to be flexible on both sides of the threshold. Source: Own calculations.

they vary in size and the standard errors on those estimates are very large. We conclude that this part of the analysis does not support the hypothesis that education matters for economic policy outcomes.

As mentioned above (see section 3), we might be concerned that our RDD estimates pick up a specific local average treatment effect (LATE). While this is of no concern for the internal validity, external validity may be harder to argue. It is possible that our weak findings for experience and our zero findings for education are driven by the specific LATE properties of our estimators. 
In the case of the experience measure, for example, we may expect that incumbent mayors who only won reelection in a close race are not as "good" candidates (compared to the average incumbent) or faced a very competent challenger. We would, therefore, expect the LATE to underestimate the more general average treatment effect (ATE). However, if the ATE was even larger, we would expect to pick it up in the OLS and FE estimates. Given that even those estimates are insignificant, we consider it unlikely that our findings are only driven by the LATE properties of our RDD specifications.

In table 6, we turn to the results for the tax rates as outcome variables ${ }^{15}$ Specifically, we test for effects on the three tax rate multipliers that are directly levied at the local level (property tax A and B as well as the local trade tax on businesses). The table is constructed similar to table 5 above.

Again, the results for experience follow a clear pattern. We find that point estimates have a negative sign throughout, a result that is consistent with the negative patterns that we also observed for debt and expenditures. In contrast to the above, we can estimate the effects on local tax rates more precisely. Both the effects on the property taxes $\mathrm{A}$ and $\mathrm{B}$ are sizable and show significance at the 5 and 10 percent level. Results for the local trade tax are also negative, but they are very small and remain insignificant ${ }^{16}$ For education, again the picture is less clear, as point estimates are jumping in sign and are insignificant throughout. Also, this is consistent with our findings above.

Figure 2 in the appendix illustrates the findings for experience graphically. For the four outcomes of debt, expenditures, and the local property taxes A and B, we graph the local fiscal measures and look for a discontinuity at the winning threshold. Similar to the results in the regression tables, we find a tendency for lower debt, expenditures and taxes, however, these trends are not necessarily significant.

Finally, in addition to our main outcome variables debt, expenditures and taxes, we also test for effects in more disaggregated spending and revenue categories. In table 12 in the appendix, we highlight the results for spending on personnel, investment spending, revenues from taxes as well as revenues from fees. The table is again constructed in the same way as table 5. Here, we find no significant effects of the mayor's experience or education on the fiscal measures of the municipalities.

\footnotetext{
${ }^{15}$ Similar to above, we use changes in the three local tax rate multipliers (over five years following the mayoral election) as the dependent variables in the regressions.

${ }^{16}$ The fact, that effects cannot be shown for the local trade tax, may in part be explained by local tax competition. While inhabitants that are exposed to property taxes are said to be immobile (especially given the relatively small effect that property taxes have on their entire tax bill), firms that pay the trade tax are more flexible and are more likely to respond to a change in taxation.
} 
Table 6: Qualification and local taxation

\begin{tabular}{|c|c|c|c|c|c|c|c|}
\hline & \multirow{2}{*}{$\frac{\mathrm{OLS}}{(1)}$} & \multirow{2}{*}{$\begin{array}{c}\mathrm{FE} \\
(2)\end{array}$} & \multicolumn{2}{|c|}{ Global parametric RDD } & \multicolumn{3}{|c|}{ Discontinuity-sample RDD } \\
\hline & & & $(3)$ & (4) & $(5)$ & $(6)$ & (7) \\
\hline & \multicolumn{7}{|c|}{ Panel 1: Experience } \\
\hline Property tax A & $\begin{array}{l}-1.17 \\
(1.14)\end{array}$ & $\begin{array}{l}-1.41 \\
(1.43)\end{array}$ & $\begin{array}{l}-3.62^{*} \\
(1.90)\end{array}$ & $\begin{array}{l}-7.19^{*} \\
(4.23)\end{array}$ & $\begin{array}{c}-7.82^{* *} \\
(3.84)\end{array}$ & $\begin{array}{l}-6.60 \\
(5.95)\end{array}$ & $\begin{array}{c}-5.05^{* *} \\
(2.32)\end{array}$ \\
\hline Property tax B & $\begin{array}{l}-1.10 \\
(1.06)\end{array}$ & $\begin{array}{c}0.12 \\
(1.34)\end{array}$ & $\begin{array}{c}-3.60^{* *} \\
(1.77)\end{array}$ & $\begin{array}{l}-4.54 \\
(3.47)\end{array}$ & $\begin{array}{l}-5.00 \\
(3.64)\end{array}$ & $\begin{array}{l}-6.38 \\
(5.61)\end{array}$ & $\begin{array}{c}-4.29^{*} \\
(2.20)\end{array}$ \\
\hline Trade tax & $\begin{array}{c}0.78 \\
(0.61)\end{array}$ & $\begin{array}{c}1.38 \\
(0.89)\end{array}$ & $\begin{array}{c}0.53 \\
(1.08)\end{array}$ & $\begin{array}{l}-0.17 \\
(2.46)\end{array}$ & $\begin{array}{l}-0.06 \\
(2.63)\end{array}$ & $\begin{array}{l}-3.66 \\
(3.82)\end{array}$ & $\begin{array}{l}-0.15 \\
(1.39)\end{array}$ \\
\hline \multirow[t]{2}{*}{ Observations } & 3,019 & 3,019 & 3,019 & 3,019 & 471 & 258 & - \\
\hline & \multicolumn{7}{|c|}{ Panel 2: Education } \\
\hline Property tax A & $\begin{array}{c}0.44 \\
(0.84)\end{array}$ & $\begin{array}{c}1.93 \\
(1.44)\end{array}$ & $\begin{array}{l}-1.47 \\
(2.69)\end{array}$ & $\begin{array}{c}1.75 \\
(5.84)\end{array}$ & $\begin{array}{c}1.67 \\
(6.38)\end{array}$ & $\begin{array}{l}1.65 \\
(9.35)\end{array}$ & $\begin{array}{l}-5.34 \\
(3.86)\end{array}$ \\
\hline Property tax B & $\begin{array}{c}0.99 \\
(0.86)\end{array}$ & $\begin{array}{c}1.37 \\
(1.46)\end{array}$ & $\begin{array}{l}-3.91 \\
(2.80)\end{array}$ & $\begin{array}{l}-1.92 \\
(5.99)\end{array}$ & $\begin{array}{l}-5.13 \\
(6.56)\end{array}$ & $\begin{array}{l}-1.83 \\
(9.48)\end{array}$ & $\begin{array}{l}-7.45^{*} \\
(3.70)\end{array}$ \\
\hline Trade tax & $\begin{array}{c}0.65 \\
(0.60)\end{array}$ & $\begin{array}{c}2.18^{* *} \\
(1.02)\end{array}$ & $\begin{array}{l}-0.48 \\
(1.80)\end{array}$ & $\begin{array}{c}0.99 \\
(4.42)\end{array}$ & $\begin{array}{c}0.23 \\
(5.15)\end{array}$ & $\begin{array}{c}7.00 \\
(7.56)\end{array}$ & $\begin{array}{l}-1.18 \\
(2.91)\end{array}$ \\
\hline Observations & 3,440 & 3,440 & 3,440 & 3,440 & 587 & 282 & - \\
\hline $\begin{array}{l}\text { Control function } \\
\text { Sample size }\end{array}$ & $\begin{array}{l}\text { none } \\
\text { full }\end{array}$ & $\begin{array}{l}\text { none } \\
\text { full }\end{array}$ & $\begin{array}{l}\text { linear } \\
\text { full }\end{array}$ & $\begin{array}{l}\text { 4th order } \\
\text { full }\end{array}$ & $\begin{array}{l}\text { linear } \\
+/-10 \%\end{array}$ & $\begin{array}{l}\text { linear } \\
+/-5 \%\end{array}$ & $\begin{array}{c}\text { linear } \\
\text { optimal }\end{array}$ \\
\hline
\end{tabular}

Notes: Significance levels: ${ }^{*} p<0.10,{ }^{* *} p<0.05,{ }^{* *} p<0.01$. Standard errors in parentheses are robust. The dependent variables for local taxes are indicated in the left column. They refer to changes in local tax multipliers over five years following the election year. Results are reported for different estimations for on-the-job experience as a mayor (sharp RDD) in panel 1 and education (fuzzy RDD) in panel 2. Note, that results for education in the fuzzy RDD refer to the second-stage IV regression and each coefficient is the estimate on the variable of whether the mayor is highly qualified instrumented from a separate first-stage regression. All regressions include linear and squared controls for the number of inhabitants in the municipalities as well as year fixed effects. Column 1 shows the OLS results, column 2 the results for a simple fixed effects estimation (with municipality fixed effects). In columns 3 and 4 we present the results of the parametric implementation (global polynomial) with control functions of first and fourth order. Results from different non-parametric implementations are reported in columns 5 to 7 . In the last column, we implemented the optimal bandwidth estimator by Imbens and Kalyanaraman (2012). The optimal bandwidth for experience ranges from $+/-35.7 \%$ for property tax B and $+/-42.9 \%$ for property tax A, for education it ranges from $+/-30.6 \%$ for trade tax and $+/-43.6 \%$ for property tax $\mathrm{B}$. All control functions are specified to be flexible on both sides of the threshold. Source: Own calculations.

We conclude that the mayor's qualification does not have strong effects on the public finances of her municipality. While the results for experience generally fall in line with our hypothesis, they are not always significant. From the analysis on education, we cannot find significant results for debt, total spending, tax rates or more disaggregated revenue and spending categories. Overall, the results are partly surprising given the highly significant electoral advantage of better qualified candidates running for the mayor's office (see section 4.1). This leaves us with an unclear picture and one question remains: Why do voters care so much about the mayor's qualification when it does not affect fiscal outcomes such as 
debt, expenditures or tax rates?

Recent studies investigated how female representation affects public finances (Svaleryd, 2009 Ferreira and Gyourko, 2011; Campa, 2011). Initially, our intention was to conduct a similar analyses here. However, as already noted in section 2.2, women are strikingly underrepresented in Bavaria's local politics. We observe less than 3.3\% female candidates and only 314 women succeeded in being elected out of 23,129 elections. Given these low numbers, we are not able to draw upon any statistical interference using the regression discontinuity design on fiscal outcomes at all. For this reason, we are not able to investigate whether female and male mayors enact different policies.

Up to this point, we have looked at general outcome variables. We asked whether more qualified mayors lower the debt burden or decrease local taxes. Implicitly, we assume that this is what voters care for. However, one of the reasons that we do not detect strong general effects of mayor qualification could be that researchers cannot observe what a good policy for the voters of a municipality really is. A more qualified mayor might indeed make good policy decisions for her local constituency, but this can involve a reduction of local debt in the one case and the financing of a large infrastructure project in the other case. To that extent, there might still be good reasons for voters to vote for the more qualified candidate, however, measuring the quality of the fiscal outcomes is a much harder task. In order to get closer to this type of analysis, we devote the following section to the analysis of the effects of specific occupational groups in the mayoral office.

\subsection{Specific professional expertise and fiscal outcomes}

This part of the analysis is concerned with the policy effects of having a member of a specific professional group become the mayor of a municipality. Specifically, we will study the fiscal effects when the mayor has a background as (1) an entrepreneur, (2) a farmer, (3) a financial professional, (4) a lawyer or (5) a public employee. As outcomes, we will again focus on local public debt. Moreover, we will investigate specific fiscal outcomes for one group in particular. For farmers, we will specifically highlight the results for the property tax rates on farmland.

Table 7 shows the main results for the effect of particular professional groups on local public debt. The table is constructed similar to table 5. We present the results for the five professional groups in five different rows. Overall, the table does not show significant effects of either professional group on the local level of debt.17

${ }^{17}$ We also employ these specific job categories in our analysis of electoral success in section 4.1 Using 
For former entrepreneurs as well as for farmers, the point estimates of the OLS, FE and RDD specifications all show a negative effect, indicating that members of those groups tend to reduce local debt. However, we do not have statistical significance on those results. For the remaining three professional groups, the results are mixed in signs throughout the different specifications and are mostly insignificant. We should add that this lack of significance for the RDD results can be a result of the fact that we rely on a small number of observations around the threshold (in contrast to the analysis above). Here, identification only comes from cases in which a member of the specific occupational group just made it into office or not. However, this is not true for the OLS and FE estimates, which are also insignificant.

In table 8, we investigate how mayors with a background as farmers enact tax policy. This is of particular interest as one of the local tax instruments specifically targets property in agricultural use (the property tax A). We can thus analyze the mayor's policy making with regard to the professional group that she belongs to.

Our results here are indeed interesting. While the OLS and FE estimation again point to a zero effect, the RDD results are much less variable and are often statistically significant (at least at the $10 \%$ level). Throughout all specifications, they point toward a positive effect of having a former farmer in the mayor's office. For the property tax A, the results range between 5.6 and 15.2 in the tax rate multiplier. As the multiplier is about 330 points on average, the effects also constitute a sizable impact. That is even more so, when we recognize that those tax rate multipliers rarely change and that the average increase of the property tax multiplier in Bavaria has been around 6-8 points per election period.

From a political economics perspective, the sign and significance of the tax effect of mayors with a background as a farmer is surprising. Considering special issue politics, we might have expected the farmer to decrease tax rates for the constituency that is closest to her. However, we find the opposite is true. The former farmer increases the local property tax on farmland (compared to a mayor of a different former profession). And more, also the general property tax B and the tax on local businesses are being increased. These results correspond well with the negative sign on the local debt that we consistently found for former farmers (although not significant).

these five categories instead of the official occupational groups does not yield other results compared to model 5 in tables 4 and 11. However, farmers enjoy a statistically significant electoral advantage of 2 percentage points in vote share and 4.5 percentage points in the probability of winning. The same holds for public employees who gain additional 4.6 percentage points in vote share and 12.0 percentage points in probability of winning. Lawyers, finance professionals, and entrepreneurs enjoy a significantly higher vote share by $2.5,1.6$, and 0.5 percentage points respectively, but do not benefit from a significant increase in their probability of winning. 
Table 7: Specific professional expertise and public debt

\begin{tabular}{|c|c|c|c|c|c|c|c|}
\hline & \multirow{2}{*}{$\frac{\text { OLS }}{(1)}$} & \multirow{2}{*}{$\frac{\mathrm{FE}}{(2)}$} & \multicolumn{2}{|c|}{ Global parametric RDD } & \multicolumn{3}{|c|}{ Discontinuity-sample RDD } \\
\hline & & & $(3)$ & (4) & $(5)$ & $(6)$ & $(7)$ \\
\hline Entrepreneurs & $\begin{array}{l}-11.01 \\
(18.64) \\
{[1,255]}\end{array}$ & $\begin{array}{l}-62.88 \\
(44.50) \\
{[1,255]}\end{array}$ & $\begin{array}{l}-24.29 \\
(34.07) \\
{[1,255]}\end{array}$ & $\begin{array}{l}-91.54 \\
(89.38) \\
{[1,255]}\end{array}$ & $\begin{array}{c}-124.08 \\
(97.71) \\
{[222]}\end{array}$ & $\begin{array}{c}-175.20 \\
(146.96) \\
{[103]}\end{array}$ & $\begin{array}{c}-137.76^{*} \\
(75.87) \\
-\end{array}$ \\
\hline Farmers & $\begin{array}{c}-44.49^{*} \\
(23.99) \\
{[787]}\end{array}$ & $\begin{array}{c}-93.25 \\
(63.87) \\
{[787]}\end{array}$ & $\begin{array}{c}-59.34 \\
(46.37) \\
{[787]}\end{array}$ & $\begin{array}{c}-26.62 \\
(116.91) \\
{[787]}\end{array}$ & $\begin{array}{c}-85.81 \\
(138.44) \\
{[149]}\end{array}$ & $\begin{array}{c}-297.76 \\
(198.45) \\
{[63]}\end{array}$ & $\begin{array}{c}-22.54 \\
(67.80) \\
-\end{array}$ \\
\hline $\begin{array}{l}\text { Finance } \\
\text { professionals }\end{array}$ & $\begin{array}{c}70.22^{* *} \\
(32.01) \\
{[608]}\end{array}$ & $\begin{array}{c}26.92 \\
(106.22) \\
{[608]}\end{array}$ & $\begin{array}{c}40.09 \\
(58.78) \\
{[608]}\end{array}$ & $\begin{array}{c}-23.06 \\
(121.67) \\
{[608]}\end{array}$ & $\begin{array}{c}181.97 \\
(175.59) \\
{[110]}\end{array}$ & $\begin{array}{c}55.83 \\
(180.34) \\
{[51]}\end{array}$ & $\begin{array}{c}-20.91 \\
(67.15) \\
-\end{array}$ \\
\hline Lawyers & $\begin{array}{c}-14.35 \\
(42.81) \\
{[280]}\end{array}$ & $\begin{array}{c}-15.71 \\
(141.77) \\
{[280]}\end{array}$ & $\begin{array}{c}15.59 \\
(75.27) \\
{[280]}\end{array}$ & $\begin{array}{c}-254.76 \\
(200.28) \\
{[280]}\end{array}$ & $\begin{array}{c}-433.97 \\
(277.63) \\
{[53]}\end{array}$ & $\begin{array}{c}-1,066.07 \\
(752.27) \\
{[21]}\end{array}$ & $\begin{array}{c}-134.62 \\
(128.48) \\
-\end{array}$ \\
\hline $\begin{array}{l}\text { Public } \\
\text { employees }\end{array}$ & $\begin{array}{c}19.44 \\
(18.87) \\
{[1,163]}\end{array}$ & $\begin{array}{c}-6.85 \\
(58.36) \\
{[1,163]}\end{array}$ & $\begin{array}{c}24.34 \\
(33.25) \\
{[1,163]}\end{array}$ & $\begin{array}{c}7.69 \\
(75.39) \\
{[1,163]}\end{array}$ & $\begin{array}{c}-71.82 \\
(98.40) \\
{[188]}\end{array}$ & $\begin{array}{c}78.27 \\
(142.49) \\
{[81]}\end{array}$ & $\begin{array}{c}4.92 \\
(42.74) \\
-\end{array}$ \\
\hline $\begin{array}{l}\text { Control function } \\
\text { Sample size }\end{array}$ & $\begin{array}{l}\text { none } \\
\text { full }\end{array}$ & $\begin{array}{l}\text { none } \\
\text { full }\end{array}$ & $\begin{array}{l}\text { linear } \\
\text { full }\end{array}$ & $\begin{array}{l}\text { 4th order } \\
\text { full }\end{array}$ & $\begin{array}{l}\text { linear } \\
+/-10 \%\end{array}$ & $\begin{array}{l}\text { linear } \\
+/-5 \%\end{array}$ & $\begin{array}{l}\text { linear } \\
\text { optimal }\end{array}$ \\
\hline
\end{tabular}

Notes: Significance levels: ${ }^{*} p<0.10,{ }^{* *} p<0.05,{ }^{* * *} p<0.01$. Standard errors in parentheses are robust. The number of observations for each regression is stated in square brackets. The dependent variable in all regressions is change in per-capita public debt over five years from the election year to the year before the next election. All regressions include linear and squared controls for the number of inhabitants in the municipalities as well as year fixed effects. Column 1 shows the OLS results, column 2 the results for a simple fixed effects estimation (with municipality fixed effects). In columns 3 and 4, we present results of the parametric implementation (global polynomial) with control functions of the first and fourth order. Results from different non-parametric implementations are reported in columns 5 to 7 . In the last column, we implemented the optimal bandwidth estimator by Imbens and Kalyanaraman (2012). The optimal bandwidth ranges from $+/-18.0 \%$ for entrepreneurs and $+/-39.7 \%$ for public employees. All control functions are specified to be flexible on both sides of the threshold. Source: Own calculations.

Our results on the effects of particular professions in the mayoral position provide only little evidence that specific experience affects local public finances. For all five professions that we examine, we find no significant effects on our main outcome variable: the level of local public debt. For the group of farmers, however, we can analyze the specific effects on a local tax instrument that is targeted directly farmers. Surprisingly, we find that mayors with a background as farmers increase all taxes, including the property tax rate on farmland. To that extent, we highlight that mayors do not act as 'professional partisans'. 
Table 8: Farmers and local taxation

\begin{tabular}{|c|c|c|c|c|c|c|c|}
\hline & \multirow{2}{*}{$\frac{\text { OLS }}{(1)}$} & \multirow{2}{*}{$\frac{\mathrm{FE}}{(2)}$} & \multicolumn{2}{|c|}{ Global parametric RDD } & \multicolumn{3}{|c|}{ Discontinuity-sample RDD } \\
\hline & & & $(3)$ & (4) & (5) & (6) & (7) \\
\hline Property tax A & $\begin{array}{c}0.55 \\
(1.41)\end{array}$ & $\begin{array}{l}-1.40 \\
(3.02)\end{array}$ & $\begin{array}{l}5.57^{*} \\
(3.22)\end{array}$ & $\begin{array}{c}9.93 \\
(6.45)\end{array}$ & $\begin{array}{c}9.99 \\
(6.98)\end{array}$ & $\begin{array}{l}15.23^{*} \\
(7.76)\end{array}$ & $\begin{array}{c}11.47^{* *} \\
(4.79)\end{array}$ \\
\hline Property tax B & $\begin{array}{c}0.65 \\
(1.38)\end{array}$ & $\begin{array}{l}-1.51 \\
(3.00)\end{array}$ & $\begin{array}{l}5.59^{*} \\
(3.21)\end{array}$ & $\begin{array}{c}9.68 \\
(6.29)\end{array}$ & $\begin{array}{l}10.93 \\
(6.90)\end{array}$ & $\begin{array}{c}14.49^{*} \\
(7.33)\end{array}$ & $\begin{array}{c}7.42^{* *} \\
(3.59)\end{array}$ \\
\hline Trade tax & $\begin{array}{c}0.38 \\
(0.93)\end{array}$ & $\begin{array}{l}-2.50 \\
(2.59)\end{array}$ & $\begin{array}{l}4.20^{* *} \\
(1.80)\end{array}$ & $\begin{array}{c}5.99 \\
(3.97)\end{array}$ & $\begin{array}{c}5.97 \\
(4.46)\end{array}$ & $\begin{array}{l}8.50^{*} \\
(4.78)\end{array}$ & $\begin{array}{c}5.96^{* *} \\
(2.24)\end{array}$ \\
\hline $\begin{array}{l}\text { Control function } \\
\text { Sample size } \\
\text { Observations }\end{array}$ & $\begin{array}{l}\text { none } \\
\text { full } \\
821\end{array}$ & $\begin{array}{l}\text { none } \\
\text { full } \\
821\end{array}$ & $\begin{array}{l}\text { linear } \\
\text { full } \\
821\end{array}$ & $\begin{array}{l}\text { 4th order } \\
\text { full } \\
821\end{array}$ & $\begin{array}{c}\text { linear } \\
+/-10 \% \\
153\end{array}$ & $\begin{array}{c}\text { linear } \\
+/-5 \% \\
66\end{array}$ & $\begin{array}{c}\text { linear } \\
\text { optimal } \\
\quad-\end{array}$ \\
\hline
\end{tabular}

Notes: Significance levels: ${ }^{*} p<0.10,{ }^{* *} p<0.05,{ }^{* * *} p<0.01$. Standard errors in parentheses are robust. Dependent variables are indicated in the left column. They refer to changes in local tax multipliers over five years after the election year. All regressions include linear and squared controls for the number of inhabitants in the municipalities as well as year fixed effects. Column 1 shows the OLS results, column 2 the results for a simple fixed effects estimation (with municipality fixed effects). In columns 3 and 4 , we present results of the parametric implementation (global polynomial) with control functions of the first and fourth order. Results from different non-parametric implementations are reported in columns 5 to 7 . In the last column, we implemented the optimal bandwidth estimator by Imbens and Kalyanaraman 2012). The optimal bandwidth ranges from $+/-34.6 \%$ for the property tax A to $+/-70.7 \%$ for property tax B. All control functions are specified to be flexible on both sides of the threshold. Source: Own calculations.

\subsection{Validity of the regression discontinuity design}

In this section, we evaluate the validity of our RDD. The RDD analyses based on close elections crucially relies on randomized variations just around the threshold. While we cannot directly test this assumption, it is possible, as Lee (2008) points out, to observe necessary (but not sufficient) conditions. In particular, we apply two implicit tests proposed by Lee (2008) and McCrary (2008).

First, we check the histograms of the frequency around the thresholds to assess the continuity of the assignment variable margin of victory (or loss). Significant discontinuities in the distribution around the threshold $\operatorname{margin}_{i}=0$ would indicate potential manipulations under which randomization would be violated and the RDD invalid. In the histograms in figure 3 in the appendix, we show that the frequency of observations shows no significant differences around the threshold. We present the histograms for the three samples used in the analyses for the education level, for experienced mayors, and for farmers. In the upper panels, we chose a wide range of the margin of victory. For experience as a mayor, the distribution is considerably skewed to the left, whereas the distributions are more uniform for education and farmers. The skewness to the left reflects the electoral advantage of in- 
cumbents. In the lower panels, we focus instead on the range of the margin of victory very close to the threshold. The upper histogram for experience differs from the two histograms for education and farmers from the increasing frequency of observations in the margin of victory for experience. Table 13 in the appendix presents the results of the formal McCrary statistic that tests for the size of the jump at the threshold and its significance level. As indicated, we find no significant differences.

Second, we highlight that the variables that were determined before treatment show no significant differences around the threshold. Table 14 in the appendix holds the findings for this particular test. We run the same RDD models as above on variables that are lagged by one period.18 If randomization indeed works, we should find no effect of treatment on those predetermined variables. Indeed, we find no effects both in the experience analysis (column 1-3) and the education analysis (columns 4-6).

As an additional test, we run two placebo regressions. Table 15 in the appendix simulates the effect if treatment was at alternative thresholds. In panel 1, we test the effects on local public debt if a higher qualified candidate obtained the mayor's office with a margin of victory of -0.05 . This means that we artificially construct the case as if a high-qualified candidate could win with just above 47.5 percent. In panel 2 , we test the opposite case, in which the high-quality candidate artificially needs more than 52.5 percent to carry a win. The results are interesting for two reasons. Firstly, we can show that there are no effects of treatment at those constructed thresholds (which would otherwise invalidate the research design). Secondly, we can compare the point estimates and standard errors to our actual treatment effects. We find that in the placebos, the point estimates and standard errors are small and undetermined in sign. Our actual treatment effects for public debt, in comparison, have a clear direction, are much larger and have larger standard errors. While we still cannot conclude that there is a treatment effect, this highlights that at the actual threshold there is more change.

Finally, we also present graphical evidence that the first stage in our fuzzy RDD in fact induced a significant difference at the threshold. Figure 4 in the appendix shows that the treatment of observing a highly educated mayor in office changes discontinuously at the threshold. If the highly educated candidate wins the elections (on the margin), we observe the probability of the mayor holding a university degree by more than $40 \%$. This is the jump in the education variable that we then use to identify the effects in the education analysis.

\footnotetext{
${ }^{18}$ To shorten the exposition, we reduced the number of specifications to the main three for both experience and education.
} 
Overall, all tests of the validity of the RDD hold. Even if our analysis showed few findings of a mayor's qualification on the fiscal outcomes of a municipality, these results are not driven by misspecification on the part of the statistical methodology.

\section{Conclusion}

In this study, we examine the importance of a politician's qualification, i.e., education and experience, on their electoral success and later fiscal outcomes. We apply regression discontinuity design methodology and use the outcomes of close elections to identify causal effects. Our analysis is based on a large panel for 2,031 municipalities with roughly 9 million inhabitants in the Germany state of Bavaria. We collected information on election results and qualification levels of mayor candidates as well as municipality budgets for these municipalities from 1950, respectively from 1984, through 2009.

Our results are twofold and puzzling. First of all, we find that the electoral success of a candidate running for the mayor's office is significantly affected by her education based on the occupation indicated on the ballot sheet. Candidates with (expected) higher education receive a higher vote share and are more likely to win the election. The same holds for candidates with on-the-job experience (incumbents). Specific job groups also positively affect electoral success.

Given the strong results for electoral success, our other results are intriguing. We find limited robust evidence that the fiscal performance of the municipality is affected either by the qualification level or the professional background of the mayor. Mayors who have been in office before tend to lower the level of debt and total municipal expenditures as well as decrease local taxes. While those effects are only sometimes significant, they show a clear tendency in the expected direction. For the analysis of education, we cannot detect any statistically significant effect of the mayor's qualification level on local debt level, spending, tax rates or more detailed revenue and spending categories. Moreover, the estimates vary largely in size and signs. This leaves us with an unclear picture and raises the question of why voters care so much about the mayor's qualification and, here in particular, the education of the mayoral candidate when it does not matter for fiscal outcomes such as debt, expenditures and tax rates.

From the normative perspective, there are multiple ways in which the state legislator could try to intervene with the qualification requirements for the mayor's position. She could limit competition for the mayor position by introducing term limits or age bars, or she could make the mayor position more attractive by increasing wages or by making the positions more 
avaible to non-locals. The results in this paper, however, indicate that those reforms, to the extent that they change the qualification level of the mayor, would make no substantial difference for the overall fiscal performance of the municipalities.

In addition to education and experience, the paper also highlights the effects of specific professional groups after they get into the mayoral office. Here, the only relevant effect on fiscal outcomes that we find is for the case in which a former farmer becomes the local mayor. We report significant effects that those candidates alter tax policy and increase all three local tax rates. This finding is again surprising, as one of the local tax instruments directly targets agricultural property.

Furthermore, we find strong evidence for a sizeable electoral disadvantage and a resulting political underrepresentation of women in Bavaria. Hence, we cannot even investigate whether female mayors realize different fiscal outcomes. The share of female candidates is simply too low with $3.3 \%$ and the number of females who win the mayor's office is even lower. This keeps us from drawing upon any statistical interference using the regression discontinuity design.

Drawing our results together, many questions remain unanswered. This opens up room for further research on the influence of a politician's characteristics on election outcomes and policy outcomes. In addition to the role of their education and professional experience, the effect of a politician's gender requires further analysis. 


\section{References}

ADE, F. (2011): "Constitutions matters: Evidence from a natural experiment at the community level," mimeo.

ADE, F., AND R. FREIER (2011a): "Divided government versus incumbency externality effect: Quasi-experimental evidence on multiple voting decisions," DIW Discussion Paper, 1121. German Institute for Economic Research, Berlin.

(2011b): "When can we trust population thresholds in regression discontinuity designs?," DIW Discussion Paper, 1136. German Institute for Economic Research, Berlin.

Besley, T., And A. CASE (1995): "Does electoral accountability affect economic policy choices? Evidence from gubernatorial term limits," The Quarterly Journal of Economics, 110(3), 769-798.

Besley, T., J. G. Montalvo, and M. Reynal-Querol (2011): "Do educated leaders matter?," The Economic Journal, 121(554), F205-227.

CAmpa, P. (2011): "Gender quotas, female politicians and public expenditures: Quasi-experimental evidence," Econpubblica Working Paper, 157.

Congleton, R. D., And Y. Zhang (2009): "Is it all about competence? The human capital of U.S. presidents and economic performance," SSRN Working Paper, 1684151.

Deutsche Bundesbank (2007): "Zur Entwicklung der Gemeindefinanzen seit dem Jahr 2000," Monatsbericht, Juli, 29-49.

Dreher, A., M. J. Lamla, S. M. Lein, and F. Somogyi (2009): "The impact of political leaders' profession and education on reforms," Journal of Comparative Economics, 37(1), 169-193.

Farvaque, É., H. Hammadou, and P. Stanek (2009): "Select your committee: The impact of central bankers background on inflation," Economie Internationale, 117(1), 99-129.

(2011): "Selecting your inflation targeters: Background and performance of monetary policy committee members," German Economic Review, 12(2), 223-238.

Ferreira, F., AND J. Gyourko (2011): "Does gender matter for political leadership? The case of U.S. mayors," NBER Working Paper Series, 17671.

FREIER, R. (2011): "Incumbency as the major advantage: The electoral advantage for parties of incumbent mayors," DIW Discussion Paper, 1147. German Institute for Economic Research, Berlin.

Gagliarducci, S., And T. NAnnicini (forthcoming): "Do better paid politicians perform better? Disentangling incentives from selection," Journal of the European Economic Association. 
Galasso, V., and T. NAnnicini (2011): "Competing on good politicians," The American Political Science Review, 105(1), 79-99.

GÖHLmann, S., And R. Vaubel (2007): "The educational and occupational background of central bankers and its effect on inflation: An empirical analysis," European Economic Review, 51(4), 925-941.

Hahn, J., P. Todd, and W. KlaAuW (2001): "Identification and estimation of treatment effects with a regression-discontinuity design," Econometrica, 69(1), 201-209.

Imbens, G. W., and K. Kalyanaraman (2012): "Optimal bandwidth choice for the regression discontinuity estimator," The Review of Economic Studies, 79(3), 933-959.

Jochimsen, B., And S. Thomasius (2012): "The perfect finance minister: Whom to appoint as finance minister to balance the budget?," DIW Discussion Paper, 1188. German Institute for Economic Research, Berlin.

LEE, D. S. (2008): "Randomized experiments from non-random selection in U.S. House elections," Journal of Econometrics, 142(2), 675-697.

LeE, D. S., And T. Lemieux (2010): "Regression discontinuity designs in economics," Journal of Economic Literature, 48(2), 281-355.

MCCRARY, J. (2008): "Manipulation of the running variable in the regression discontinuity design: A density test," Journal of Econometrics, 142(2), 698-714.

McDermott, M. L. (2005): "Candidate occupations and voter information shortcuts," The Journal of Politics, 67(1), 201-219.

MCKAY, J. (2004): "Women in German politics: Still jobs for the boys?," German Politics, 13(1), 56-80.

Mechtel, M. (2011): "It's the occupation, stupid! Explaining candidates' success in low-information elections," mimeo.

PaOla, M. D., And V. Scoppa (2011): "Political competition and politician quality: Evidence from Italian municipalities," Public Choice, 148(3-4), 547-559.

Persson, P., And E. Zhuravskaya (2011): "Elite capture in the absence of democracy: Evidence from backgrounds of Chinese provincial leaders," SSRN Working Paper, 1506709 .

Persson, T., G. Roland, and G. Tabellini (1997): "Separation of powers and political accountability," The Quarterly Journal of Economics, 112(4), 1163-1202.

Pettersson-Lidbom, P. (2008): "Do parties matter for economic outcomes? A regression-discontinuity approach," Journal of the European Economic Association, 6(5), 1037-1056.

Rogoff, K. S., And A. Sibert (1988): "Elections and macroeconomic policy cycles," The Review of Economic Studies, 55(1), 1-16. 
SAJons, C. J. (2011): "Essays in immigration economics and political economy," Ph.D. thesis, Universitat Pompeu Fabra, Departament d'Economia i Empresa, Barcelona.

SvalerYD, H. (2009): "Women's representation and public spending," European Journal of Political Economy, 25(2), 186-198.

Thistlethwaite, D. L., and D. T. Campbell (1960): "Regression-discontinuity analysis: An alternative to the ex post facto experiment," Journal of Educational Psychology, 51(6), 309-317. 


\section{Appendix}

Figure 1: Sample ballot paper

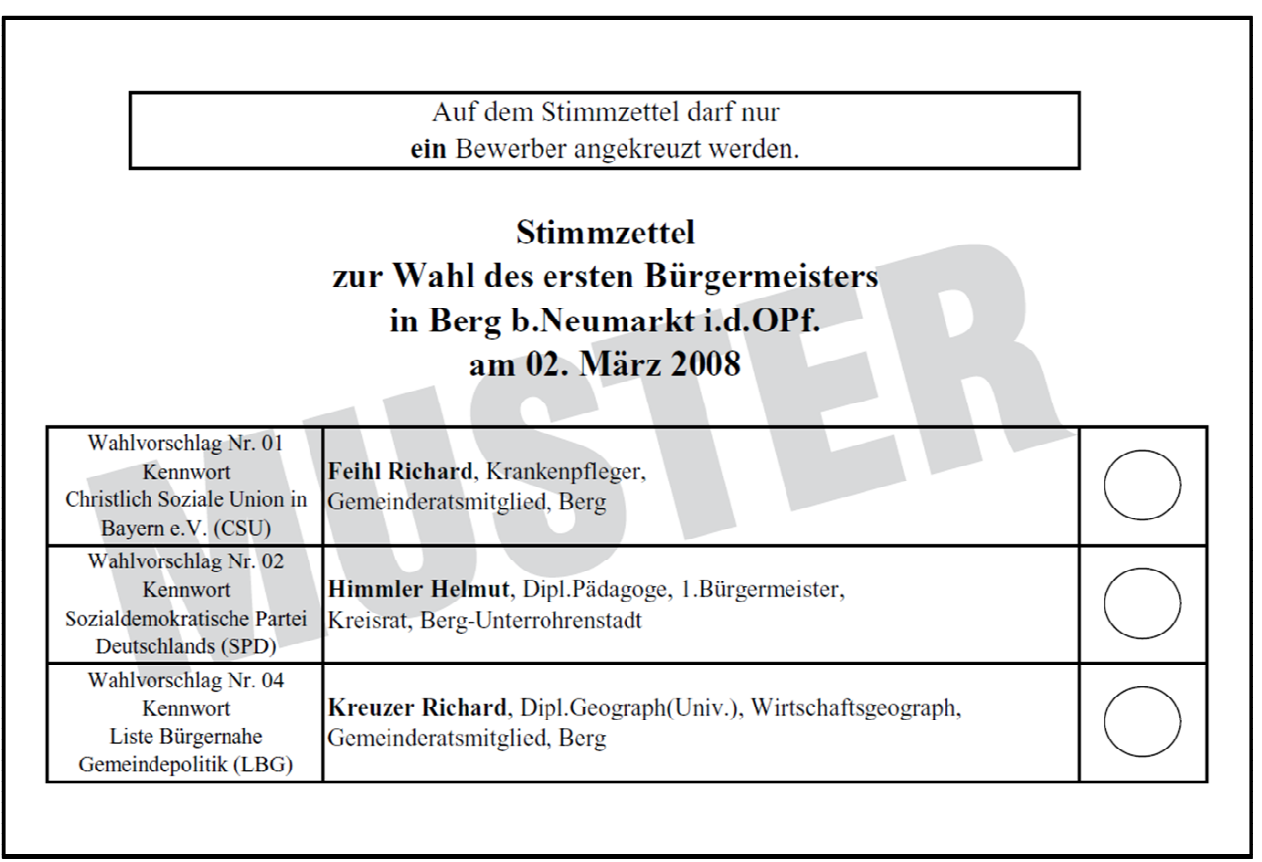

Source: Sample ballot sheet for the mayoral elections in the municipality Berg bei Neumarkt in der Oberpfalz that took place on March 2, 2008. The ballot sheet states the names of the three candidates and the respective party affiliation: Richard Feihl (CSU), Helmut Himmler (SPD), and Richard Kreuzer (local independent party list). Additionally, the profession of each candidate is indicated. The first candidate works as a hospital nurse and is a member of the local council. The second candidate is the incumbent and holds a university degree in education. The third candidate holds a university degree in geography and works as an economic geographer. Source: Bulletin of the municipality, January 2008.

Table 9: Data set - descriptive statistics of election data

\begin{tabular}{|c|c|c|c|c|c|}
\hline Variable & Observations & Mean & Std. dev & Min & $\operatorname{Max}$ \\
\hline Number of voters & 43,371 & 2,971 & 3,637 & 82 & 38,461 \\
\hline Dummy for mayor status & 43,371 & 0.391 & 0.488 & 0 & 1 \\
\hline Interaction voters and mayor status & 43,371 & 0.093 & 0.223 & 0 & 3.846 \\
\hline Dummy for professions requiring a university degree & 43,128 & 0.168 & 0.374 & 0 & 1 \\
\hline Share of university graduates according to profession & 25,391 & 0.361 & 0.425 & 0 & 1 \\
\hline Interaction voters and share of university graduates & 25,391 & 0.174 & 0.349 & 0 & 3.706 \\
\hline Dummy for female candidates & 43,371 & 0.033 & 0.179 & 0 & 1 \\
\hline
\end{tabular}

Notes: The table shows the descriptive statistics for variables from the electoral data used in the analysis. Source: Own calculations, based on the data provided by the state statistical office of Bavaria. 
Figure 2: Main result - experience and fiscal outcomes
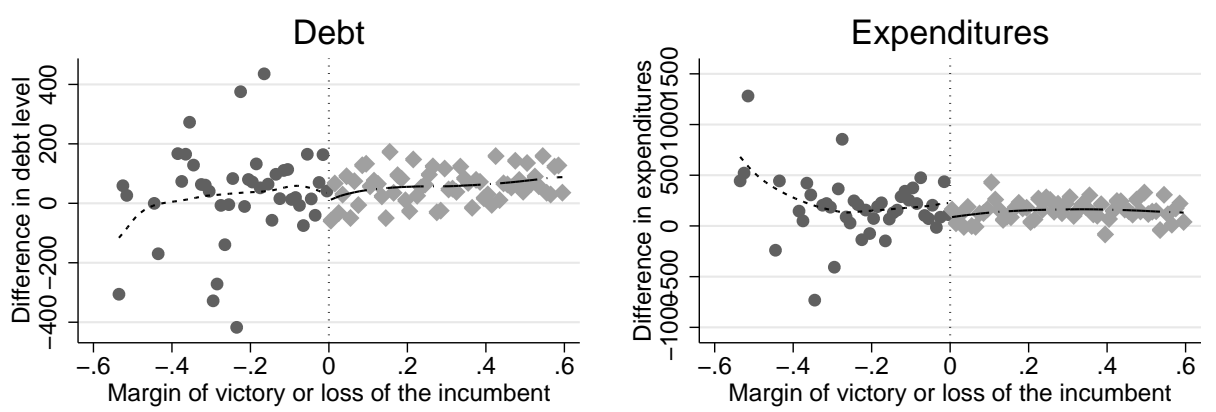

Property tax A
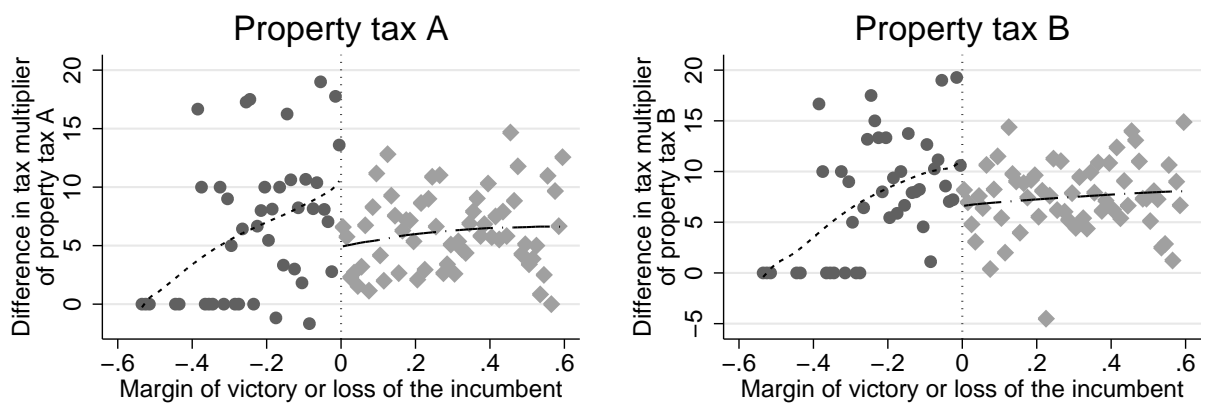

Notes: This figure illustrates the effect of having an experienced (i.e., re-elected) mayor in office on fiscal outcome variables: local public debt per capita (upper left panel), total spending per capita (upper right), spending on personnel per capita (lower left) and the multiplier of the local property tax A (lower right). We only include elections in which an incumbent mayor runs. Then, we measure the margin of victory of the incumbent against her best opponent. Just right of the thresholds are thus elections in which the incumbent just won. The observations just left have the incumbent just losing. For clarity, the data have been grouped in bins, each bin representing an interval of 1 percent in the margin of victory. The outcome variable on the horizontal axis is the difference of the respective variable over 5 years following the election. The line fitted onto the data is based on a local kernel regression using endogenous Epanechnikov weights. Source: Own calculations. 


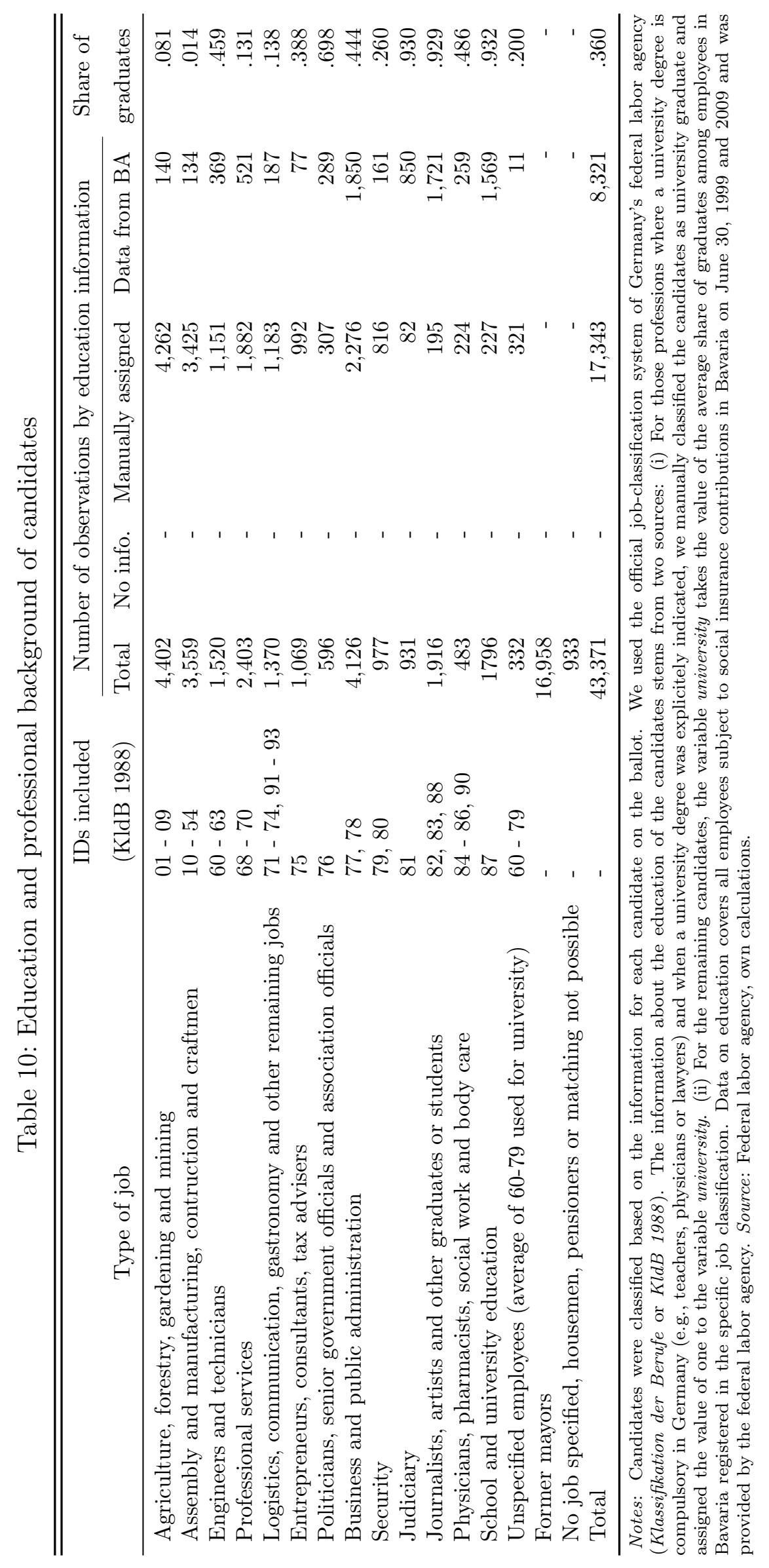


Table 11: Electoral success and characteristics of mayoral candidates: Vote share

\begin{tabular}{|c|c|c|c|c|c|}
\hline & \multicolumn{5}{|c|}{ OLS } \\
\hline & (1) & $(2)$ & $(3)$ & (4) & $(5)$ \\
\hline Incumbent & $\begin{array}{c}0.408^{* * *} \\
(0.005)\end{array}$ & $\begin{array}{c}0.415^{* * *} \\
(0.006)\end{array}$ & $\begin{array}{c}0.354^{* * *} \\
(0.007)\end{array}$ & $\begin{array}{c}0.354^{* * *} \\
(0.007)\end{array}$ & $\begin{array}{c}0.338^{* * *} \\
(0.009)\end{array}$ \\
\hline $\begin{array}{l}\text { Interaction } \\
(\# \text { of voters } * \text { incumbent })\end{array}$ & & & $\begin{array}{c}0.257^{* * *} \\
(0.017)\end{array}$ & $\begin{array}{c}0.251^{* * *} \\
(0.017)\end{array}$ & $\begin{array}{c}0.249 * * * \\
(0.017)\end{array}$ \\
\hline Dummy university & & $\begin{array}{c}0.036^{* * *} \\
(0.007)\end{array}$ & & & \\
\hline University & & & $\begin{array}{c}0.031^{* * *} \\
(0.010)\end{array}$ & $\begin{array}{c}0.031^{* * *} \\
(0.010)\end{array}$ & $\begin{array}{l}0.024^{*} \\
(0.013)\end{array}$ \\
\hline $\begin{array}{l}\text { Interaction } \\
\text { (\# of voters } * \text { university) }\end{array}$ & & & $\begin{array}{l}0.071^{* * *} \\
(0.018)\end{array}$ & $\begin{array}{c}0.069^{* * *} \\
(0.018)\end{array}$ & $\begin{array}{c}0.070^{* * *} \\
(0.019)\end{array}$ \\
\hline Female candidate & & & & $\begin{array}{c}-0.096^{* * *} \\
(0.014)\end{array}$ & $\begin{array}{c}-0.100^{* * *} \\
(0.014)\end{array}$ \\
\hline $\begin{array}{l}\text { Set of Dummies for Jobs (F-Stat) } \\
\text { (p-value in parentheses) }\end{array}$ & & & & & $\begin{array}{l}12.81 \\
(0.00)\end{array}$ \\
\hline Observations & 37,414 & 37,236 & 36,591 & 36,591 & 36,591 \\
\hline $\mathrm{R} 2$ & 0.40 & 0.40 & 0.40 & 0.40 & 0.41 \\
\hline
\end{tabular}

Notes: Significance levels: ${ }^{*} p<0.10,{ }^{* *} p<0.05,{ }^{* * *} p<0.01$. Standard errors in parentheses are robust and clustered on the level of each individual municipality election. All results presented are derived from OLS regressions and always include year and county fixed effects that are not shown here. Furthermore, the regressions include a set of dummy variables for the party of the candidate and for the respective total number of candidates in elections with more than one candidate which are not presented either. The dependent variable is an indicator variable of whether the respective person won the mayor's office in this election. The regression in column 1 highlights the effect of a candidate being the incumbent in an election. In columns 2 and 3, we add variables on the education level of the candidate. First, we add a dummy indicating whether a candidate holds a university degree with certainty (university and university of applied sciences). Second, we include our constructed measure of the expected education level as well as its interaction with the number of voters (in $10 \mathrm{tsd}$ ). In column 4 we include dummy variables for whether the candidate is female. Finally, in column 5 we add a set of dummies for the 14 job categories described in table 10 in the appendix (the table here highlights the F-test statistic for joined significance and the p-value of that test statistic is given in parentheses). Source: Own calculations. 
Table 12: Qualification and specific expenditure and revenue categories

\begin{tabular}{|c|c|c|c|c|c|c|c|}
\hline & \multirow{2}{*}{$\begin{array}{c}\text { OLS } \\
(1)\end{array}$} & \multirow{2}{*}{$\begin{array}{l}\mathrm{FE} \\
(2)\end{array}$} & \multicolumn{2}{|c|}{ Global parametric RDD } & \multicolumn{3}{|c|}{ Discontinuity-sample RDD } \\
\hline & & & (3) & (4) & $(5)$ & (6) & (7) \\
\hline & \multicolumn{7}{|c|}{ Panel 1: Experience } \\
\hline Spending on personnel & $\begin{array}{c}4.34 \\
(5.51)\end{array}$ & $\begin{array}{c}2.56 \\
(3.44)\end{array}$ & $\begin{array}{c}6.10 \\
(5.90)\end{array}$ & $\begin{array}{c}-5.40 \\
(10.45)\end{array}$ & $\begin{array}{l}-1.43 \\
(6.84)\end{array}$ & $\begin{array}{c}8.65 \\
(11.93)\end{array}$ & $\begin{array}{l}-1.14 \\
(7.00)\end{array}$ \\
\hline Investment spending & $\begin{array}{l}-26.14 \\
(20.86)\end{array}$ & $\begin{array}{l}-25.12 \\
(26.37)\end{array}$ & $\begin{array}{l}-18.30 \\
(35.00)\end{array}$ & $\begin{array}{l}-20.06 \\
(67.71)\end{array}$ & $\begin{array}{c}29.41 \\
(74.22)\end{array}$ & $\begin{array}{l}-80.74 \\
(94.71)\end{array}$ & $\begin{array}{l}-12.00 \\
(49.58)\end{array}$ \\
\hline Revenues from taxes & $\begin{array}{c}-16.04^{* * *} \\
(5.85)\end{array}$ & $\begin{array}{l}-2.70 \\
(11.74)\end{array}$ & $\begin{array}{l}-10.13 \\
(10.34)\end{array}$ & $\begin{array}{c}2.96 \\
(21.69)\end{array}$ & $\begin{array}{l}-1.02 \\
(20.13)\end{array}$ & $\begin{array}{c}6.43 \\
(29.30)\end{array}$ & $\begin{array}{l}-23.41 \\
(19.41)\end{array}$ \\
\hline Revenues from fees & $\begin{array}{l}11.32 \\
(12.13)\end{array}$ & $\begin{array}{c}5.37 \\
(5.72)\end{array}$ & $\begin{array}{c}10.70 \\
(12.42)\end{array}$ & $\begin{array}{l}-1.80 \\
(19.35)\end{array}$ & $\begin{array}{c}-3.95 \\
(11.09)\end{array}$ & $\begin{array}{c}8.08 \\
(17.16)\end{array}$ & $\begin{array}{c}-5.05 \\
(10.28)\end{array}$ \\
\hline \multirow[t]{2}{*}{ Observations } & 3,019 & 3,019 & 3,019 & 3,019 & 471 & 258 & - \\
\hline & \multicolumn{7}{|c|}{ Panel 2: Education } \\
\hline Spending on personnel & $\begin{array}{c}1.01 \\
(1.73)\end{array}$ & $\begin{array}{l}-0.89 \\
(3.23)\end{array}$ & $\begin{array}{l}-0.79 \\
(5.26)\end{array}$ & $\begin{array}{c}2.11 \\
(11.98)\end{array}$ & $\begin{array}{c}7.56 \\
(13.31)\end{array}$ & $\begin{array}{c}4.81 \\
(18.86)\end{array}$ & $\begin{array}{l}-5.30 \\
(6.14)\end{array}$ \\
\hline Investment spending & $\begin{array}{c}-0.91 \\
(16.11)\end{array}$ & $\begin{array}{l}-2.88 \\
(31.33)\end{array}$ & $\begin{array}{c}48.30 \\
(52.42)\end{array}$ & $\begin{array}{c}46.86 \\
(127.55)\end{array}$ & $\begin{array}{c}37.86 \\
(154.48)\end{array}$ & $\begin{array}{c}13.12 \\
(225.18)\end{array}$ & $\begin{array}{c}98.30 \\
(82.18)\end{array}$ \\
\hline Revenues from taxes & $\begin{array}{c}6.65 \\
(6.17)\end{array}$ & $\begin{array}{c}5.22 \\
(12.30)\end{array}$ & $\begin{array}{c}18.97 \\
(17.81)\end{array}$ & $\begin{array}{c}83.69^{* *} \\
(36.36)\end{array}$ & $\begin{array}{c}43.96 \\
(36.13)\end{array}$ & $\begin{array}{c}32.12 \\
(55.50)\end{array}$ & $\begin{array}{l}38.06 \\
(31.20)\end{array}$ \\
\hline Revenues from fees & $\begin{array}{c}4.36 \\
(3.45)\end{array}$ & $\begin{array}{c}5.93 \\
(5.83)\end{array}$ & $\begin{array}{c}10.34 \\
(10.24)\end{array}$ & $\begin{array}{l}12.13 \\
(27.19)\end{array}$ & $\begin{array}{c}24.72 \\
(30.54)\end{array}$ & $\begin{array}{c}42.02 \\
(44.99)\end{array}$ & $\begin{array}{c}5.71 \\
(13.84)\end{array}$ \\
\hline Observations & 3,440 & 3,440 & 3,440 & 3,440 & 587 & 282 & - \\
\hline $\begin{array}{l}\text { Control function } \\
\text { Sample size }\end{array}$ & $\begin{array}{l}\text { 4th order } \\
\text { full }\end{array}$ & $\begin{array}{l}\text { linear } \\
+/-10 \%\end{array}$ & $\begin{array}{l}\text { linear } \\
\text { optimal }\end{array}$ & & $\begin{array}{l}\text { 4th order } \\
\text { full }\end{array}$ & $\begin{array}{l}\text { linear } \\
+/-10 \%\end{array}$ & $\begin{array}{l}\text { linear } \\
\text { optimal }\end{array}$ \\
\hline
\end{tabular}

Notes: Significance levels: ${ }^{*} p<0.10, * * p<0.05, * * * p<0.01$. Standard errors in parentheses are robust. The dependent variables for specific expenditure and revenue categories are indicated in the left column. Results are reported for different estimations for on-the-job experience as a mayor (sharp RDD) in panel 1 and education (fuzzy RDD) in panel 2. Note, that results for education in the fuzzy RDD refer to the second stage IV regression and each coefficient is the estimate on the variable whether the mayor is highly qualified instrumented from a separate first stage regression. All regressions include linear and squared controls for the number of inhabitants in the municipalities as well as year fixed effects. Column 1 shows the OLS results, column 2 the results for a simple fixed effects estimation (with municipality fixed effects). In columns 3 and 4 , we present results of the parametric implementation (global polynomial) with control functions of first and forth order. Results from different nonparametric implementations are reported in columns 5 to 7 . In the last column, we implemented the optimal bandwidth estimator by Imbens and Kalyanaraman (2012). The optimal bandwidth for experience ranges from $+/-19.3 \%$ for spending on personnel and $+/-27.3 \%$ for revenues from local taxes, for education it ranges from $+/-32.0 \%$ for investment spending and $+/-62.7 \%$ for spending on personnel. All control functions are specified to be flexible on both sides of the threshold. Source: Own calculations. 
Figure 3: Histograms of assignment variables
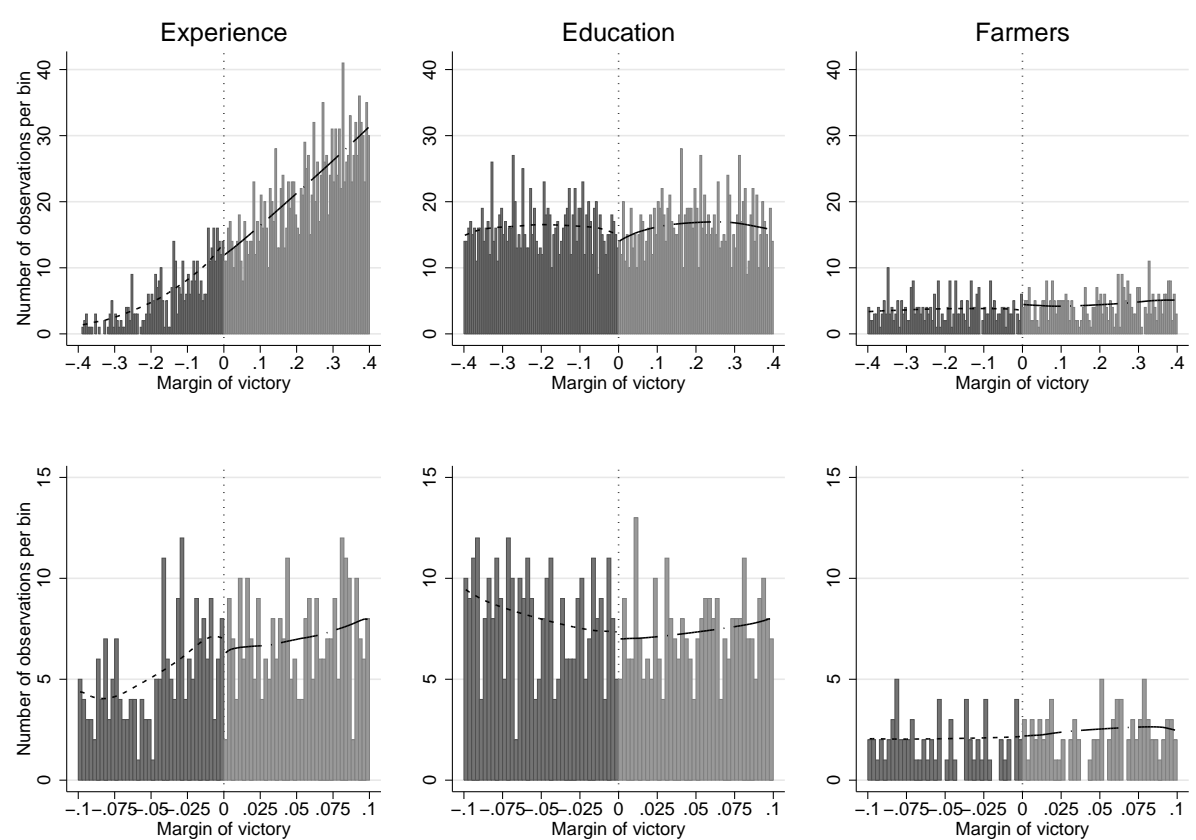

Notes: This figure presents the frequencies of observations for the analysis of on-the-job experience (lefthand side), education (center) and financial expertise (right-hand side). The data is ordered by the assignment variable margin of victory (or loss). The upper panel shows the frequencies within a margin of victory of $+/-40$ percentage points and each bin represents an interval of 0.5 percentage point in the margin of victory. In the lower panel, the graphs are zoomed in further and represent the frequencies within bins of 0.25 percentage points in the margin of victory. Source: Own calculations.

Table 13: McCrary test results

\begin{tabular}{lccc}
\hline \hline & Experience & Education & Farmers \\
\hline Discontinuity estimate & -0.113 & -0.108 & 0.329 \\
(log difference in height) & $(0.147)$ & $(0.127)$ & $(0.221)$ \\
& & & \\
Used bin size & 0.008 & 0.011 & 0.022 \\
Used bandwidth & 0.171 & 0.208 & 0.268 \\
\hline
\end{tabular}

Notes: Significance levels: ${ }^{*} p<0.10,{ }^{* *} p<0.05,{ }^{* * *} p<0.01$. Standard errors are shown in parentheses. This table reports the results of the test proposed by McCrary (2008) and its STATA implementation 'DCdensity.ado'. Source: Own calculations. 
Table 14: RDD validity: Predetermined variables

\begin{tabular}{|c|c|c|c|c|c|c|}
\hline & \multicolumn{3}{|c|}{ Experience } & \multicolumn{3}{|c|}{ Education } \\
\hline & $\begin{array}{l}\text { Global } \\
\text { (1) }\end{array}$ & $\begin{array}{c}\text { Lim. Sample } \\
(2)\end{array}$ & $\begin{array}{c}\text { Opt. Band } \\
(3)\end{array}$ & $\begin{array}{l}\text { Global } \\
\text { (4) }\end{array}$ & Lim. Sample & $\begin{array}{c}\text { Opt. Band } \\
(6)\end{array}$ \\
\hline Debt per capita in $t-1$ & $\begin{array}{c}31.34 \\
(79.57)\end{array}$ & $\begin{array}{c}47.30 \\
(77.25)\end{array}$ & $\begin{array}{c}8.13 \\
(47.12)\end{array}$ & $\begin{array}{c}-4.71 \\
(26.94)\end{array}$ & $\begin{array}{c}46.02 \\
(52.18)\end{array}$ & $\begin{array}{c}11.84 \\
(36.10)\end{array}$ \\
\hline Expenditures per cap. in t- 1 & $\begin{array}{l}-138.89 \\
(90.85)\end{array}$ & $\begin{array}{c}-162.03^{*} \\
(94.03)\end{array}$ & $\begin{array}{c}-117.31^{*} \\
(67.22)\end{array}$ & $\begin{array}{l}-34.19 \\
(41.57)\end{array}$ & $\begin{array}{l}-44.28 \\
(62.02)\end{array}$ & $\begin{array}{l}-67.00 \\
(54.72)\end{array}$ \\
\hline Property tax A in t-1 & $\begin{array}{l}12.93 \\
(9.31)\end{array}$ & $\begin{array}{l}12.47 \\
(9.71)\end{array}$ & $\begin{array}{c}14.70^{* *} \\
(7.35)\end{array}$ & $\begin{array}{l}-0.62 \\
(3.55)\end{array}$ & $\begin{array}{c}6.33 \\
(7.66)\end{array}$ & $\begin{array}{c}2.32 \\
(5.76)\end{array}$ \\
\hline Property tax B in $t-1$ & $\begin{array}{c}7.65 \\
(8.24)\end{array}$ & $\begin{array}{c}6.51 \\
(8.52)\end{array}$ & $\begin{array}{c}9.49 \\
(6.01)\end{array}$ & $\begin{array}{l}-1.49 \\
(2.99)\end{array}$ & $\begin{array}{c}7.74 \\
(6.45)\end{array}$ & $\begin{array}{c}5.81 \\
(4.22)\end{array}$ \\
\hline Trade tax in $\mathrm{t}-1$ & $\begin{array}{l}7.22^{*} \\
(4.34)\end{array}$ & $\begin{array}{c}1.73 \\
(4.63)\end{array}$ & $\begin{array}{c}3.53 \\
(3.11)\end{array}$ & $\begin{array}{c}0.60 \\
(1.44)\end{array}$ & $\begin{array}{c}2.11 \\
(2.87)\end{array}$ & $\begin{array}{l}-1.06 \\
(2.59)\end{array}$ \\
\hline $\begin{array}{l}\text { Control function } \\
\text { Sample size }\end{array}$ & $\begin{array}{l}\text { 4th order } \\
\text { full }\end{array}$ & $\begin{array}{l}\text { linear } \\
+/-10 \%\end{array}$ & $\begin{array}{l}\text { linear } \\
\text { optimal }\end{array}$ & $\begin{array}{l}4 \text { th order } \\
\quad \text { full }\end{array}$ & $\begin{array}{l}\text { linear } \\
+/-10 \%\end{array}$ & $\begin{array}{l}\text { linear } \\
\text { optimal }\end{array}$ \\
\hline $\begin{array}{l}\text { Notes: Significance levels: }{ }^{*} p<0 \text {. } \\
\text { that we use as the outcome variabl } \\
\text { on-the-job experience as a mayor ( } \mathrm{s} \\
\text { in the fuzzy RDD refer to the sec } \\
\text { highlighly qualified instrumented fro } \\
\text { of inhabitants in the municipalities } \\
\text { polynomial) with a control function } \\
2 \text { and } 5 \text {. In the columns } 3 \text { and } 6, \\
\text { functions are specified to be flexible }\end{array}$ & $\begin{array}{l}0, * * p<0.05 \\
\text { in the regres } \\
\text { arp RDD) in } \\
\text { nd stage IV } \\
\mathrm{n} \text { a separate } \mathrm{f} \\
\text { s well as year } \\
\text { f fourth order } \\
\text { implementec } \\
\text { on both sides }\end{array}$ & $\begin{array}{l}{ }^{* *} p<0.01 . \text { Sta } \\
\text { ion is indicated in } \\
\text { columns } 1-3 \text { and e } \\
\text { egression and eacl } \\
\text { irst stage regressior } \\
\text { fixed effects. Colur } \\
\text { Results from limi } \\
\text { the optimal band } \\
\text { of the threshold. } S\end{array}$ & $\begin{array}{l}\text { ndard errors in } \\
\text { the left colum } \\
\text { ducation (fuzzy } \\
\text { coefficient is } \\
\text {. All regression } \\
\text { nn } 1 \text { and } 4 \text { pres } \\
\text { ted sample regr } \\
\text { lwidth estimato } \\
\text { ource: Own cal }\end{array}$ & $\begin{array}{l}\text { entheses are } 1 \\
\text { Results are re } \\
\text { D) in column } \\
\text { estimate on } \\
\text { clude linear a } \\
\text { results of the } \\
\text { ons (within } 10 \\
\text { Imbens and }\end{array}$ & $\begin{array}{l}\text { obust. The predet } \\
\text { ported for differen } \\
\text { s 4-6. Note, that } \\
\text { he variable whetl } \\
\text { ad squared control } \\
\text { parametric implen } \\
\% \text { margin) are rep } \\
\text { Kalyanaraman }\end{array}$ & $\begin{array}{l}\text { ermined variable } \\
\text { estimations for } \\
\text { esults education } \\
\text { er the mayor is } \\
\text { for the number } \\
\text { entation (global } \\
\text { prted in columns } \\
12 \text {. All control }\end{array}$ \\
\hline
\end{tabular}


Table 15: RDD validity: Placebo test

\begin{tabular}{|c|c|c|c|c|c|c|}
\hline & \multicolumn{3}{|c|}{ Experience } & \multicolumn{3}{|c|}{ Education } \\
\hline & $\begin{array}{l}\text { Global } \\
\quad(1)\end{array}$ & $\begin{array}{c}\text { Lim. Sample } \\
(2)\end{array}$ & $\begin{array}{l}\text { Opt. Band } \\
(3)\end{array}$ & $\begin{array}{l}\text { Global } \\
\quad(4)\end{array}$ & Lim. Sample & $\begin{array}{c}\text { Opt. Band } \\
(6)\end{array}$ \\
\hline & \multicolumn{6}{|c|}{ Panel 1: Placebo - 5 percent } \\
\hline \multirow[t]{2}{*}{ Debt per capita } & $\begin{array}{c}14.60 \\
(69.66)\end{array}$ & $\begin{array}{c}23.00 \\
(66.82)\end{array}$ & $\begin{array}{c}17.89 \\
(35.29)\end{array}$ & $\begin{array}{c}7.85 \\
(24.32)\end{array}$ & $\begin{array}{l}-27.01 \\
(37.55)\end{array}$ & $\begin{array}{l}-43.26 \\
(34.70)\end{array}$ \\
\hline & \multicolumn{6}{|c|}{ Panel 2: Placebo +5 percent } \\
\hline Debt per capita & $\begin{array}{c}57.02 \\
(103.54)\end{array}$ & $\begin{array}{c}8.74 \\
(101.35)\end{array}$ & $\begin{array}{c}-12.32 \\
(56.19)\end{array}$ & $\begin{array}{c}9.43 \\
(24.35)\end{array}$ & $\begin{array}{c}42.33 \\
(84.30)\end{array}$ & $\begin{array}{l}-55.50 \\
(36.78)\end{array}$ \\
\hline $\begin{array}{l}\text { Control function } \\
\text { Sample size }\end{array}$ & $\begin{array}{l}\text { 4th order } \\
\text { full }\end{array}$ & $\begin{array}{l}\text { linear } \\
+/-10 \%\end{array}$ & $\begin{array}{l}\text { linear } \\
\text { optimal }\end{array}$ & $\begin{array}{l}\text { 4th order } \\
\quad \text { full }\end{array}$ & $\begin{array}{l}\text { linear } \\
+/-10 \%\end{array}$ & $\begin{array}{l}\text { linear } \\
\text { optimal }\end{array}$ \\
\hline
\end{tabular}

Notes: Significance levels: $* p<0.10,{ }^{* *} p<0.05,{ }^{* * *} p<0.01$. Standard errors in parentheses are robust. The table presents two placebo tests in which we artifically change the vote threshold at which a mayor is elected. In panel 1 , the thought experiment is that a specific candidate obtained the mayor office also if she lost the election with at most 5 percent. In panel 2, we look at the reverse placebo in which we treat candidates to need more than a 5 percent vote margin to carry the win. The outcome variable are indicated in the left column. Results are reported for different estimations for on-the-job experience as a mayor (sharp RDD) in columns 1-3 and education (fuzzy RDD) in columns 4-6. Note, that results education in the fuzzy RDD refer to the second stage IV regression and each coefficient is the estimate on the variable whether the mayor is highly qualified instrumented from a separate first stage regression. All regressions include linear and squared controls for the number of inhabitants in the municipalities as well as year fixed effects. Column 1 and 4 present results of the parametric implementation (global polynomial) with a control function of fourth order. Results from limited sample regressions (within 10\% margin) are reported in columns 2 and 5 . In the columns 3 and 6 , we implemented the optimal bandwidth estimator by Imbens and Kalyanaraman (2012). All control functions are specified to be flexible on both sides of the threshold. Source: Own calculations. 
Figure 4: First stage of fuzzy RDD (education)

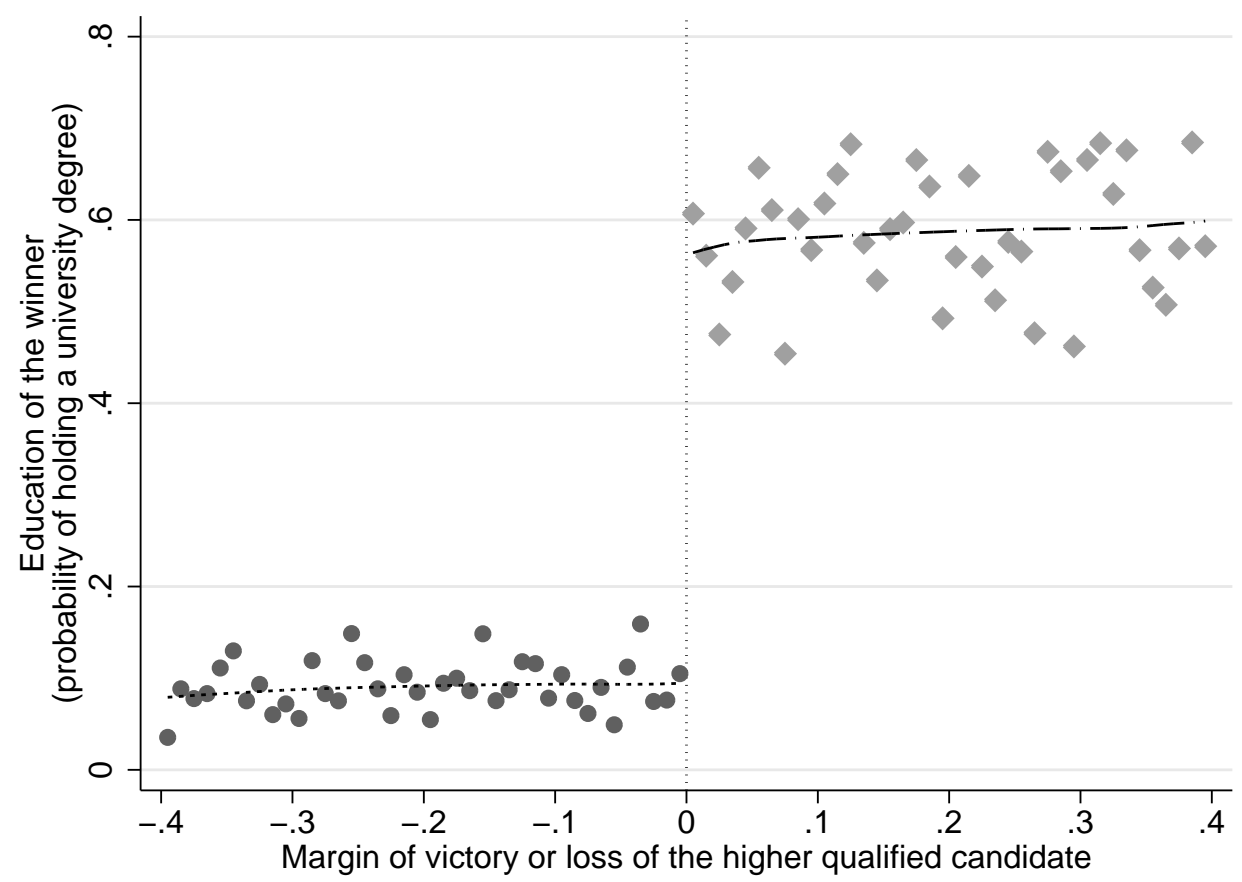

Notes: This figure graphically illustrates the validity of the instrument (first stage results) used in the analysis for the effect of education of the mayor. We have organized the data as follows. For every election, we took the two best candidates and compared their education level. Then, we measure the margin of victory of the better qualified candidate over the less qualified. Just right of the 0 thresholds are thus elections in which the high education candidate just won, while the observations just left have those candidates just losing. Given that the first stage indeed works, we should observe a clear jump in the average education level between observations just left and just right of the threshold. We present this graph to show that this is indeed the case. We highlight the jump in the fuzzy design (described above). For clarity the data have been grouped in bins, each bin representing an interval of 1 percent in the margin of victory. The outcome variable on the horizontal axis is the average education level of the elected mayors in each bin. The line fitted onto the data is based on a local kernel regression using endogenous Epanechnikov weights. Source: Own calculations. 